\title{
Öğretmenler ile Lise ve Üniversite Öğrencilerindeki Narsisizm Kişilik Özellikleri Benlik Saygısı ve Duygu Gereksinimi Arasındaki İlişkiler
}

DOI: $10.26466 /$ opus.406591

\author{
Mehmet Ertuğrul Uçar \\ ${ }^{*}$ Dr. Öğr. Üyesi Aksaray Üniversitesi, Eğitim Fakültesi, Aksaray / Türkiye \\ E-Posta: ertugrulucar@gmail.com ORCID: 0000-0002-7202-3856 \\ *Türkolog, Özel Niğde Final Temel Lisesi, Niğde / Türkiye \\ E-Posta: bilgekonal@gmail.com ORCID: 0000-0003-4128-5690 \\ Öz
}

Narsisizm; kendini diğer insanlardan üstün görme, insanlar tarafindan saygı ve hayranlık duyulma beklentisine girme ile nitelendirilen bir kişilik özelliğidir. Bazı psikologlar, narsisizmin abartılı ya da aşırı şişirilmiş yüksek bir benlik saygısı ile ilişki olduğunu öne sürmektedirler. Bu bakış açısıyla benlik saygısı narsistik kişilik özelliğini artırmaktadır. Benlik saygısı, bireylerin kendilerini ne kadar değerli hissettiklerini ifade eder. Kişilik, psikolojinin önemli alanlarından biridir ve örgütlenmiş duygusal, bilişsel, toplumsal özellikler bütünü olarak ele alınmaktadır. Kişiliğe ilişkin çok farklı yaklaşımlar öne sürülmüştür ancak en fazla kullanılan, Beş Faktör Kişilik Kuramı olarak kabul görmektedir. Bu yaklaşım bağlamında kişilik, beş faktör altında toplanabilmektedir: Dışa dönüklük, sorumluluk, uyumluluk, deneyime açıklık ve duygusal denge. Hem kişilik özellikleri hem de benlik saygısı narsisizm üzerinde etkilidir. Bazı araştırmalar narsisizm eğilimlerinin yaşa bağhl olarak değgiştiğini bir başka ifade ile farklı gelişim dönemlerinde yükselip azaldığım ortaya koymaktadır. Alanyazın ışığında bu araştırmanın temel amacı; kişilik özelliklerinden dışa dönüklük, uyumluluk, duygusal denge, sorumluluk ve deneyime açıklık kişilik boyutlarıla duygulara yaklaşma ve duygulardan kaçınma ile benlik saygısının lise ve üniversite öğrencileri ile öğretmenlerde narsisizmi yordayıp yordamadığıı ve gruplar arası farklılık olup olmadı̆̆ını araştırmaktır. Bu amaçla çoklu regresyon modeli oluşturulmuş ve varyans analizi yapılmıştır. Araştırma grubu toplam olarak 826 öğretmen, lise ve üniversite öğrencisinden oluşmaktadır (\%61.3 kadın, \%38.7 erkek). Regresyon analizinde deneyime açıklk, uyumluluk, duygusal denge ve benlik saygısının narsisizmi anlamlı olarak yordadığı saptanmıştır. Varyans analizi sonucuna göre ise narsisizm puan ortalamalarında gruplar arası anlaml farklılı bulunmuştur. Yapılan $t$ testi sonucuna göre üniversite grubunda narsisizm puan ortalamaları kadınlar ve erkekler arasında farka işaret etmektedir.

Anahtar Kelimeler: Narsisizm, Benlik Saygısı, Duygu Gereksinimi, Kişilik

OPUS @ C Uluslararası Toplum Araştırmaları Dergisi-International Journal of Society Researches ISSN:2528-9527 E-ISSN : 2528-9535

http://opusjournal.net 


\title{
Relationships Between Narcissism Personality Trait Need for Affect and Self Esteem At Teacher, Univer- sity and High School Student
}

\begin{abstract}
Narcissism is a personality trait characterized by a sense of superiority and a desire for respect and admiration from others. A common belief, both in psychology and in popular culture, is that narcissism represents a form of excessive self-esteem. Some psychologist suggests that narcissism related an exaggerated form of high self-esteem or inflated self-esteem. So that self-esteem increase narcissist personality trait. Self-esteem indicates whether people have a low or high sense of their overall self-worth. Personality deals with organized traits which are emotional, cognitive, and social. Various approaches have been proposed to examine personality but the Big-Five Personality Theory which suggests personality traits can be assessed under the five-factor has begun to come to the fore. These factors are extraversion, agreeableness, emotional stability, conscientiousness and openness to experience. Both personality traits and self-esteem effect on narcissism. Both personality traits and self esteem effect on narcissism. Some studies assert that narcissistic personality tendencies are change with age or increase and decrease different development stage. In light of the literature the aim of this study is to examine whether extraversion, agreeableness, emotional stability, conscientiousness and openness to experience, emotion approach and emotion avoidance and selfesteem's predict narcissism. Research group consisted of 826 (61.3\% female, 38.7\% male) teachers, high school and university students. The preliminary analyses showed that extraversion, agreeableness, emotional stability, conscientiousness and openness to experience and self-esteem's predict narcissism. Firstly regression analyzed showed that openness to experience, agreeableness, emotional stability and self-esteem significantly predicts narcissism. Second one way anova analyses show that there are significantly differences between high school student and university student and teacher groups. $t$ test shows that there is significantly difference between male and female in narcissism score at university student. Male's narcissism scores are higher than females in university student.
\end{abstract}

Keywords: Narcissism, Self-Esteem, Need For Affect, Personality 
Öğretmenler ile Lise ve Üniversite Öğrencilerindeki Narsisizm Kişilik Özellikleri Benlik Saygısı ve Duygu Gereksinimi Arasındaki İlişkiler

\section{Giriş}

Etimolojik bağlamda Yunanca narke (duyarsızlık) sözcügü ile ilişkilendirilen narsisizm terimi, çıkış noktasını mitolojideki "Narkissos Efsanesi ${ }^{1}$ " den alır. Benlik hakkında aşırı olumlu ve abartılı bir kanıla açıklanan terim, bu düzlemde düşünüldügünde "kibirlilik, benmerkezcilik, kendini beğenmişlik, gösterişçilik" gibi davranış örüntülerine karşlık gelmektedir (Twenge ve Campbell, 2015). Hem psikolojik hem de kültürel bir durumu tanımlayan kavram, psikoloji literatürüne ise Ellis (1898) tarafından kazandırılmış; özellikle bu dönemde kendi bedenine tam bir tatmin elde edene kadar bakan, onu okşayan, seven bir bireyin sapkınlık tutumu ile ilişkilendirilmiştir (Kızıltan, 2000).

Günümüze kadar kuramsal bakış açılarına göre farklı dinamiklerle açıklanan narsisizmin bazı araştırmacılar tarafından insan doğasındaki sağlıklı şekilleri ve iyi oluşla ilişkisi üzerinde durulurken (Kohut, 1991; Watson, Little, Sawrie ve Biderman, 1992; Rhodewalt ve Morf, 1995; Watson, Hickman ve Morris, 1996; Rhodewalt, Madrian ve Cheney, 1998); bazı araştırmacılar tarafından ise terimin olumsuz ve zarar verici boyutları vurgulanmıştır (Reich, 1954; Kernberg, 1975; Lasch, 1979; Cooper ve Ronningstam, 1992, akt. Rose, 2002). Psikanalitik düzlem değerlendirildiğinde narsisizmin ilk olarak Freud (1914) tarafından ele alındığ1 görülmektedir. Buna göre Freud (1914), narsisizmi libido kavramı merkezinde benliğin içgüdüsel olarak kendini koruyucu yönü ile açıklamış; terimi birincil ve ikincil narsisizm olarak kavramlaştırmıştır. Birincil narsisizmde başlangıçtan beri benlikte bulunan libidinal enerji nesnelere yönelmemekte, bu durumu da güçlü ve kusursuz olma duygularının eşlik ettiği benlik şişmesi izlemektedir. İkincil narsisizmde ise diş dünyada yaşanan engellenmeler ve düş kırıklıkları sonucu, libidonun nesnelerden çekilerek yeniden egoya dönmesi durumu görülmektedir (Geçtan, 2015). Freud'a göre narsisizm, canlı her varlığa haklı olarak bir ölçüde

\footnotetext{
${ }^{1}$ Narkissos'un kusursuz güzelliği, diğer su perileri gibi Ekho'yu da derinden etkiler. Fakat Narkissos'a büyük bir aşkla kendini açan Ekho, genç adam tarafından çok sert bir şekilde reddedilir. Bu utanç verici reddedilis, onu hasta ederek yok olmasına neden olur. Bunun üzerine diğer su perileri, tanrılara Narkissos'un cezalandırılması için talepte bulunurlar ve genç adama platonik bir aşk yaşama cezası verilir. Günler sonra berrak bir göle rastlayan genç adam, burada kendi yansımasını görerek bu yansımaya aşık olur. Ona her dokunuşunda kaybolan bu imgeden kendini ayıramaz ve en nihayetinde ona sarılmak için uzandığında göle düşüp boğularak ölür.
} 
atfedilebilecek bir özellik, diş dünyadan uzaklaşan libidonun benliğe yönetilmesinden kaynaklanan libidinal bir yatırımdır (Freud, 1914).

Genel olarak ele alındığında psikanalistler, narsisizm sorununun kaynağını erken çocukluk dönemiyle örtüştürmektedirler (Lowen, 2016). $\mathrm{Bu}$ durum nesne ilişkileri ve kendilik psikolojisi kuramlarında da görülmekte, her iki kuramda da narsisizmin oluşumundaki odak, yaşamın erken evrelerinde ebeveyn-çocuk ilişkisindeki bozukluk ya da yetersizliğin bir ürünü olarak değerlendirilmektedir. Buna göre çocuk, olumsuz yaşantılara bağlı olarak ilkel bazı savunma mekanizmaları geliştirmektedir. Dolayısıyla çocuğun yaşamı ilerleyen süreçte çaresiz bırakıldığ1 koşullara karşı geliştirdiği ilkel ve uyum bozucu davranış örüntülerinden oluşmaktadır. Bu düzlemde ebeveynin, çocuğun gelişim evresine özgü gereksinimlerini karşılamak yerine onu reddederek düş kırıklığına uğratması buna bağlı olarak da çocuğun olumsuz duygular geliştirmesi ve yalnızlaşması durumları söz konusu olmaktadır (Ozan, Kırkpınar, Aydın, Fidan ve Oral, 2008). Nitekim narsist bireyin diğer insanlarla olan duygusal bağları oldukça zayıftır ve sevgiden yoksun bu zayıf bağların boşluğunu beğeni toplama isteği doldurmaktadır. Bu eğilim de narsisizmin kendini sevmek ve tanımaktan çok kendinden kaçmaya ve kendine yabancılaşmaya yol açtığını gösterir (Geçtan, 2015). Sonuç olarak psikanalitik bakış açısıyla narsisizm ya psikoseksüel gelişim basamaklarında aksamalar ya da nesne tasarımlarındaki saplanmalar ile ortaya çıkmaktadır (Doğan, Uğurlu ve Canat, 2007).

Kohut (1977) ve Kernberg'in (1974/1975) çalışmaları da narsisizm kavramlaştırmalarına ivme kazandırmış ve klinik narsisizmin gelişmesinde önemli rol oynamıştır (Atay, 2009). Kernberg (1975) narsisizmi, “büyüklenmecilik, empati (eş duyum) yoksunluğu, duygusal boşluk hissi, benmerkezcilik" ifadeleri çerçevesinde açıklarken patolojik bir bakış açısı geliştirmiş ve bireyin çocukluk dönemine atıfta bulunarak olumsuz yaşantılarına karşı geliştirdiği bir savunma mekanizması olarak nitelendirmiştir. Kohut ise (1971) sağlıklı gelişimsel bir yapı olarak değerlendirdiği narsisizme ek olarak patolojik narsisizmi olağan gelişim düzleminde gelişimsel bir duraklama şeklinde nitelendirmiş, ikisi arasında bir devamlılık olduğuna vurgu yapmıştır. Dolayısıyla Gabbard' in (2000) da değerlendirdiği gibi Kohut'un gelişim düzleminde ele aldığı narsisizmi, Kernberg' de hatalı bir gelişim -patolojik bir durum- olarak görmek 
mümkündür (Anlı ve Bahadır, 2007). Kohut'un (1977) bakış açısıyla narsisizme yol açan kusurlar; çocukluk yaşantısından benlik yapısına yansıyan öz saygı eksikliği, bireyin kendini aşırı boyutlarda değersiz hissetmesi, depresif duygusal denge ve diğerleri tarafından reddedilme düşüncesi olarak gözükmektedir (Özakkas, 2006). Narsisizm, daha önce de değinildiği gibi psikanalitik kuramclar tarafından bir savunma mekanizması ya da davranışı ve yaratıcılığı yönlendiren bir enerji kaynağı gibi görülse de ilerleyen süreç, olgunun patolojik bir bozukluğa ulaşabileceği üzerine odaklanmıştır (Campbell ve Foster, 2007). Nitekim narsistik kişilik bozukluğu, patolojik bir bozukluk olarak değerlendirilerek 1980 y1lında APA tarafından yayınlanan Zihinsel Bozuklukların Tanısal ve İstatistiksel El Kitabı'nın (The Diagnostic and Statistical Manual of Mental Disorders - DSM III) 3. baskısında ilk kez yer almıştır (Atay, 2009). 2013'te yayımlanan DSM-V' te ise tanı eksen yapısındaki değişikliklerle birlikte ilk öze sadık kalınarak erken erişkinlik döneminde başlayan ve çeşitli koşullarda kendini gösteren büyüklenmeciliği, hayranlık gereksinimini, eş duyum (empati) yoksunluğunu içeren bir bozukluk olarak vurgulanmaktadır. Patolojik narsisizmde bireyler özellikle kendilerini diğerlerinden üstün görme eğilimindedirler. Bu bireylerin kendilerinden ne kadar emin olduklarını ve diğerlerinin fikirlerine ihtiyaç duymadıklarını gösteren ise şişirilmiş bir benlik saygısı olarak gözükmektedir. Ancak bunun tam tersi olarak bu bireylerin, çevreden gelen yorumlarla beslendiği görülmekte ve dolayısıyla dış dünyaya yansıtılanın aksine içsel süreçte bu bireylerin düşük benlik saygısına sahip olduğu düşünülmektedir (Kernberg, 1975). Lowen (2016) klinik tecrübelerinden yola çıkarak bu bireyler için duygularını -benliklerini- inkar edenler tanımlamasını kullanır. Duygulardan yoksun hareket ederek duygulardan kaçınma ve olayları kendi çkarları doğrultusunda değiştirme eğilimli bu bireyler, tüm güç ve kontrolün kendilerinde olmasını isterler; onlar için ne hissettiklerinden çok nasıl göründükleri önem taşımaktadır.

Bazı araştırmalarda birey için pozitif yönde işlediği bulgulanan normal narsisizm (Campbell ve Foster, 2007), bireyi olumlu yönde motive ederek kendisi, çevresi ve çevrenin beklentileri doğrultusunda diş dünya ile başa çıkmada uyumlu hale getirebilmektedir (Rozenblatt, 2002). Bunu; bireyin benliğine güç, kendini önemli hissetme, çekicilik gibi özellikleri atfetmesiyle açıklamak mümkündür. Aynı zamanda narsisizme eği- 
limli bireylerin dışadönük ve kendini geliştirmeyi amaçlayan, deneyimlere açı bireyler olduğu görülmektedir ki bu çabaların dinamiğinde kendini diğerlerine iyi ve eşsiz gösterme motivasyonu yatmaktadır (Twenge, Konrath, Foster, Campbell ve Bushman, 2008). Kendine odaklanma da bu bireylerin yüksek öz güven ve öz değere sahip olmalarını sağlarken bireyi dışarıdan gelen eleştirilere karşı koruma işlevi üstlenmektedir (Akhtar, 1989). Dolayısıyla benliğe ilişkin olumlu algının, normal narsisizm ile ilişkilendirildiği görülmektedir (Pincus ve Lukowitsky, 2010). Ancak bireyin sosyal ilişkilerinde rahat olmasını, liderlik özelliği bulundurmasını, kendini ve yeteneklerini değerlendirmede iyi hisler içinde olmasını sağlayan normal narsisizm; bu değişkenler düşünüldüğünde pozitif yönde değerlendirilse de çevreyle olan ilişkilerin sürdürülmesini engellemesi ya da yanıltan öz bilgi bağlamında oldukça zararlı sonuçlar doğurabilmektedir (Foster ve Campbell, 2007). Twenge ve Campbell'a (2015) göre bunun nedeni nesnel ölçümlerin aksine narsist bireylerin diğerlerinden daha zeki, yaratıcı, güzel görünümlü, hak sahibi olmalarına inanmaları ve buna bağlı olarak geliştirdikleri üstünlük alg1larıdır. Bu üstünlük algısı ve eşsiz olma hissi ise hem bu bireyleri diğerlerini anlamaktan hem de çevredekilerle duygusal olarak sıcak, derin ve sevgi dolu ilişkiler kurmaktan alıkoymaktadır. Sonuç olarak narsisizm eğilimli bireyler için diğerlerini anlamaya çalışmak ve onların duygularının farkında olmak önem taşımamakta, diğerlerinin varlığı onun üstünlüğünü onaylamak ve çıkarlarını sağlamakla ilişkili görülmektedir. Biricik olduğuna inanan narsist birey; dişa dönüklük, iddialılık, kendinden son derece emin olma ve abartılı gösterişte bulunma gibi özellikleriyle de ön plana çımaktadır (Atay, 2010).

Narsisizm eğilimlerinin kimi araştırmacılar tarafından benlik saygısı ile de ilişkilendirildiği görülmektedir. Rosenberg'e (1965) göre benlik saygısı "bireyin kendisine karşı olumlu ve olumsuz tutumları"nı kapsar. Birey kendini değerlendirirken olumlu bir tutum içindeyse benlik saygısı yüksek; olumsuz bir tutum içindeyse benlik saygısı düşük olmaktadır. Yüksek benlik saygısına sahip bireyler kendilerini toplumda değerli bir kişi görme (Baumeister ve Tice, 1986), kendisini kabul etme ve üstün niteliklerine odaklanma eğilimindedirler ve risk almaya daha açıktırlar (Baumeister, Tice, ve Hutton, 1989). Bununla beraber benlik saygisı pek çok araştırmada ortalamanın üzerinde puan almış ve araştırmacılar bu 
durumu, benlik saygısının yükselme eğilimi içinde olması ile açıklamışlardır (Baumeister ve ark., 1989). Twenge ve Campbell (2015) ise bu bulguların tüm zamanlardan daha yüksek bir eğilim içinde olduğunu ve buna bağlı olarak yüksek benlik saygısıyla ilişkilendirilen bireycilik, iddialılık ve dışa dönüklük gibi kendine hayranlıkla örtüştürülen özelliklerdeki yüksek puanlara dikkat çekmiştir. Yüksek benlik saygısı mutluluk, kendini iyi hissetme ve girişkenlik ya da gruplar içinde kendini daha iyi ifade etme ile ilişkili gözükse de (Baumeister, 2013) yapılan araştırmalar benlik saygısının abartılı ve dengesiz biçimde artırılmasının narsisizme yol açabileceğini bulgulamıştır (Baumeister Campbell, Krueger ve Vohs, 2003).

Narsisizm eğilimleri cinsiyet bağlamında değerlendirildiğinde literatürde farklı bakış açıları ve bulguların olduğu görülmektedir. Özellikle Freud (1914) tarafından kadınlar için vurgulanan bu eğilimin nesnel ölçümlerle her iki cinsiyette de görülebileceği bulgulanmış; bazı araştırmacılar eşitliğe vurgu yaparken (Lasch, 2006), bazı araştırmacılar (Akhtar ve Thomson, 1982; Philipson, 1985) ise bu eğilimlerin erkeklerde daha fazla görüldüğü bulgulamıştır. Araştırmalarda çıkar elde etme ile ilişkilendirilen "sömürücülük", ayrıcalık vurgulayan "hak iddia etme" boyutları ve güçle açıklanan "otorite" boyutundan erkeklerin kadınlardan kayda değer şekilde yüksek puan aldıkları saptanmıştır (Grijalva ve ark., 2015).

Genel popülasyondaki narsisizm eğilimlerini ölçmek isteyen kişilik psikolojisi ve sosyal psikoloji araştırmacıları, öncül bazı çalışmaların ardından (Raskin ve Terry, 1979; Emmons, 1987) 40 maddelik Narsistik Kişilik Envanteri' ni (NPI-40) oluşturmuşlardır (Raskin ve Terry, 1988). 2000'li yıllara kadar popülaritesini sürdüren NPI-40'in ise Ames, Rose ve Anderson (2006) tarafından benlik saygisı ve Beş Faktör Kuramı (McCrea ve Costa, 1987) kişilik boyutları ölçüt alınarak 16 maddelik kısa formu geliştirilmiştir. Çalışmada narsistik eğilimlerin özellikle dışa dönüklük ve deneyime açıklıkla pozitif; duygusal denge ve uyumlulukla negatif yönlü ilişkisi ortaya konmuştur.

\section{Faktör Kişilik Modeli}

Büyük Beşli olarak da anılan Beş Faktör Kişilik Kuramı (Big-Five Perso- 
nality Theory), bütün kişilik özelliklerinin evrensel bağlamda gözleme dayalı olarak beş temel boyutta ele alınıp sınıflandırılmasını öngörmekte (McCrae ve Costa, 2003) ve kişilik alanının yeterli bir şekilde saptanabilmesi için beş temel boyuta ihtiyaç duyulduğu sayıltısına dayanmaktadır (Berry, Poortinga, Breugelmans, Chasiotis, ve Sam, 2015). Bu boyutlar ise dişa dönüklük (extraversion), uyumluluk (agreeableness), duygusal denge (emotional stability), sorumluluk (conscientiousness) ve deneyime açıklıktan (openness to experience) oluşmaktadır.

Dışa dönüklük boyutu; sosyal beceri, girişkenlik ve konuşkanlık gibi özellikleri içermektedir (Morsünbül, 2014). Genel olarak bir bireyin sosyal ilişkilerindeki rahatlı seviyesiyle ilintili olan boyutun bir ucunda aşırı dışa dönükler, diğer ucunda ise içe dönükler bulunur (Burger, 2016). Boyuttan yüksek puan alan bireyler; sosyal, eğlenceyi seven, samimi, konuşkan, aktif ve çevresine hakim olmayı seven tiplerdir (McCrae ve Costa, 1987). Uyarıcı sosyal çevre aramaya eğilimli olan bu bireylerin sempatik olmaları da önemli özellikleri arasında sayılmaktadır (Berry ve ark., 2015). İçe dönükler ise çekingen, sessiz, sakin, kapall, yalnız kalma eğilimi gösteren ve diğerleriyle arasına mesafe koyma eğilimli bireylerdir (McShane ve Von Glinow, 2005). Bunların yanı sıra dışa dönüklük kişilik özelliğinin, narsisizmle de diğer insanlar ile birlikte olma bağlamında (Aslan, 2008) ilintili olduğu görülmektedir. Narsisizm eğilimli bireylerin genel itibariyle yüksek benlik saygısına bağlı olarak dişa dönüklük kişilik özellikleri sergilediği düşünülmektedir (Twenge ve Campbell, 2015).

Uyumluluk boyutu; sempatik, saygıll, samimi ve anlayışlı olma gibi özellikleri içerirken (Morsünbül, 2014) bireylerin insancil yönünü ön plana çıkarmaktadır (Digman, 1990). Boyuttan yüksek puan alan bireylerin; yardımsever, güvenilir ve şefkatli olma yönleri dikkat çeker (Burger, 2016), aynı zamanda bu özellikler onları kibar ve duyarlı da yapar (Berry ve ark., 2015). Empati kurma ve çatışma çözümünde yapıcı olma eğilimleri, uyumlu kişiler için vurgulanan diğer özelliklerdir (Weitten, Hammer ve Dunn, 2001). Boyuttan düşük puan alan bireyler; davranışsal bağlamda işbirliğinden kaçma, inatçı ve kaba olma gibi özelliklere sahiptirler. Çevrelerine karşı kayıtsız, güvensiz ve şüpheci yaklaşan bu bireyler (McCrae ve Costa, 1987), aynı zamanda çıarları ve inançları için uzlaşmak yerine kavgayı seçme eğilimindedirler (Burger, 2016). 
Duygusal denge (nevrotik olmama) boyutu; eleştiriye açıklık, sakinlik, rahatlık gibi özellikler üzerine kuruludur (Morsünbül, 2014). Dolay1sıyla boyut, bireylerin kişilerle ve çevreyle uyumunun yanında duygusal kararlılık durumunu da yordar. Denge durumunda bireylerden sakin, iyi uyum gösteren; aşırı ve uyumsuz duygusal tepkiler vermeyen bireyler olmaları beklenir (Burger, 2016). Nevrotik bireyler-duyguları sıkça değişme eğiliminde olan - duygusal sıkıntılar yaşayan, endişeli, sinirli ve özgüveni düşük bireyler içinse beklenen, boyuttan düşük puan almalarıdır (McCrae ve Costa, 1987). Berry ve arkadaşlarına (2015) göre de duygusal dengesizlik, kaygiya ve gerginliğe neden olmakla beraber düşmanca davranışlara meyli de artırmaktadır.

Sorumluluk boyutu; öz disiplin, düzen ve başarma ile ilişkili özellikleri içermektedir (Morsünbül, 2014). Dolayısıyla boyutta öne çıkan, bireyin öz disipline ne kadar sahip olduğu ve kendini ne ölçüde kontrol edebildiği ile ilgili özellikleridir. Boyuttan yüksek puan alan bireylerin hazzı erteleyebilen, sorumluluk sahibi, disiplinli davranan, verimli ve üretken olmayı hedefleyen kişiler olduğu söylenebilir (McCrae ve John, 1992). Bunların yanı sıra başarma duygusu yüksek, organize olmakta zorlanmayan, plan yapabilme özelliğine sahip bu bireyler (Costa ve McCrae, 1995), etik ilke ve değerlere belirgin şekilde bağlılık gösterme eğilimindedirler (Neuman ve Wright, 1999).

Deneyime açıklık boyutu; yaratıcılık, merak ve yeni düşüncelere açık olma gibi özellikleri içerir (Morsünbül, 2014). Dolayısıyla boyut, bireylerin gelenekselin ötesine geçerek yenilikleri ne derece kabul etme eğiliminde olduklarıyla ilintilidir. Yeni görüşleri kabul etme isteği, analitik düşünebilme, zihinsel merak ve geniş bir hayal gücü (Burger, 2016), deneyime açıklığın aynı zamanda entelektüelliği de içermesini sağlar (Berry ve ark., 2015). Boyuttan yüksek puan alanlar; çok yönlü düşünebilen, yeniliklere açı, özgün fikirler üretebilen, hayal gücü kuvvetli, sanata karşı duyarlı, cesur, değişiklikten korkmayan ve meraklı bireyler olarak nitelendirilebilirler (Costa ve McCrae, 1992). Boyuttan düşük puan alan bireylerde ise geleneksele bağlılık ve bununla ilgili olarak yeni bir şeylerdense alışılageleni seçme eğilimi vardır (Burger, 2016). Boyut, genç ve ileri yaşta olan bireyler için farklı sonuçlar vermiş, araştırmalar gençlerin ileri yaş grubuna göre boyuttan önemli bir şekilde yüksek puan aldıklarını ortaya koymuştur (Costa ve ark., 1986). 
Beş Faktör Kuramı yukarıda sözü edilen beş boyutu; kalıcı, değişmez ve evrensel olarak nitelendirerek biyolojik temele dayandirmakta (Costa ve McCrae, 1995; McCrae ve Costa, 2003), her yerde ve durumda değişmeyen, bireye özgü sabit davranış kalıplarının altında yatan kişilik boyutlarını ortaya koymaya çalışmaktadır (Berry ve ark., 2015). Normal ve anormal kişilik yapılarını anlamaya yönelik çalışmalar için zemin oluşturan kuram (Taymur ve Türkçapan, 2012); kişilik bozukluklarını, normal kişilik özelliklerinin zayıf ya da aşırı uçları olarak değerlendirmekte ve klinik psikolojide Beş faktörlü modelin kullanılabileceğini önermektedir (Costa ve McCrea, 1992).

\section{Duygu Gereksinimi}

Duygular; bir bireyin mutlu, kızgın, üzgün, öfkeli, korkmuş olması gibi temel hislerini kapsayan (Uçar ve Aliyev, 2017), uyum sağlayıcı ve karmaşık bir örüntüyü ifade etmektedir (Zajonc, 1980; Izard, 2007). Duyguların kavramsallaştırılma çabaları tarihsel olarak milattan önceye dayanmakla birlikte psikoloji literatüründe genel olarak çerçevenin çevresel/fizyolojik (Tolman, 1923; Dollard, Miller, Doob, Mowrer, ve Sears 1939; Paulhan, 2013) ya da merkezi/zihinsel (Leventhal ve Scherer, 1987; Zajonc, 1980; Lazarus, 1991; Epstein, 1998) olarak şekillendiği görülür. Popülaritesini koruyan tartışma ise özellikle duyguların bilişsel bir sürecin uzantısı mı yoksa bilişten ayrı bir süreç olarak mı işlediği üzerinedir. Maio ve Esses'e (2001) göre de duygular sıklıkla bazı özel biliş durumlarını takip etmektedir ve bilişsel süreçler de sıklıkla bir miktar duygu içermektedir. Dolayısıyla duygular ve biliş arasında karşılıklı bir etkileşim vardır.

Hem bilişsel hem de uyumsal işlevleriyle insan yaşamının vazgeçilmez parçaları olan duygular, öznel özellik gösterirler. Bu düzlemde bilgi işleme sürecindeki bireysel farklılıklara bağlı olarak bireylerin uyarıcılar karşısında yaşadığı duygu gereksinimleri de farklılaşabilir (Mario ve Essen, 2001). Duygu gereksinimi, bireylerin duygu içeren etkinlik veya durumlara yaklaşmasına ya da bu durumlardan kaçınmasına ilişkin genel bir güdülenme düzeyini ifade eder (Duyan, Uçar ve Kalafat, 2011). Bireylerin kendi ve diğerlerinin duygularını anlama isteği, duygu gereksinimiyle ilgilidir. Maio ve Esses'e (2001) göre insanlar bir duygu dene- 
yimi yaşadıklarında kendilerinin ve diğerlerinin duygularını anlamak için gereksinim duyarlar; bu gereksinim, duygulara yaklaşmak ve duygulardan kaçınmak şeklinde ortaya çıkan güdülenmeye yol açar. Bireylerden beklenen, rahatsız edici duygulardan kaçınma güdüsüyken; duygulara yaklaşma güdüsünde ise olumlu duygu yaşantıları ön plana çıkmaktadır (Lang, 1995; Maio ve Esses, 2001). Duygulara yaklaşma ve duygulardan kaçınma güdülerinin farklı yaşantılara bağlı olarak ortaya çıkmasının yanında duygular, insanların yargılarını ve davranışlarını şekillendirmede de etkilidir (Maio ve Esses 2001). Duyguların yargıları etkilemesi, bilişsel sonuçlar ortaya çıkarmakla birlikte duygu gereksinimi fazla olan bireylerde baskın gözükmektedir. Duygulara yaklaşma gereksinimi fazla olan kişiler yaşanılan durumları ayrıntılı olarak düşünme, sorgulama ve tartışma eğilimlerine bağlı olarak oluşan ve yeni şeyler öğrenme ihtiyacına yol açan bir güdülenme içindedirler. Bu durum, yeni bir şeyler öğrenirken eski bilgilerle yeni öğrenilenlerin çatışması ya da var olan bilgilerin genişlemesinde yaşanan zorlamalardan ötürü bireyde duygusal bir gerilime yol açmaktadır. Bu örüntü duygulara yaklaşma gereksinimi olan bireylerin istediği bir durum olarak değerlendirilmektedir. Tartışmalı konular ve bu konulardaki uç fikirler yine bu bireyler için oldukça çekici gözükmektedir ki uç fikirlere dair yapılan tartışmaların bu bireylere güçlü duyguları deneyimleme fırsatı vermesi bu durumu açıklar niteliktedir. Buradan hareketle duygu gereksinimi yüksek kişilerin, yeni ve farklı konular öğrenmeye daha açık ve istekli hale geldiği düşünülmektedir. Duygu gereksinimi yüksek olan kişiler, sosyal gruplara karşıda güçlü tutumlar sergileyebilirler; bunun altında yatan dinamik, grupların güçlü duyguların deneyimlenmesini kolaylaştırması ve optimal düzeyde uyarılmayı sağlaması ile ilgilidir (Blankstein, Flett, Koledin, ve Bortolotto, 1989). Bu düzlemde nefret hisleri ya da yüksek kabul, içsel olarak memnun edici olabilir (Maio ve Esses, 2001). Duygu yoğunluğu olan aktivitelere katılma olasılığının - roman veya şiir okumak, korku filmi ya da tiyatro izlemek- yüksek düzeyde duygu gereksinimi olan bireylerin düşük olanlara göre daha fazla olduğu görülmektedir. Nitekim düşük duygu gereksinimi, yani duygulardan kaçnma eğilimi, bireyi bu tür etkinliklerden uzaklaştırmaktadır. Genel bağlam, bireylerin "duygulara yaklaşma"ya "duygulardan kaçınma"dan daha fazla güdülendiğini göstermektedir. Bu eğilim, yaklaşma güdüsünün 
bireyde içsel olarak daha fazla doyum sağlama özelliğiyle ilişkilendirilmektedir (Schwarz, 1990; Maio ve Esses, 2001). Duygu gereksinimi düzeylerindeki farklılaşmanın bir diğer nedeni de öğrenme süreçleridir. Örneğin bireylerin yetiştirilme sürecinde öğrendikleri cinsiyet rolleri, kadın ve erkeklerin hangi duygulara yaklaşıp hangilerinden kaçınacağ1nı öngörmektedir (Fujita, Diener, Sandvik, 1991). Kring ve Gordon'a (1998) göre erkekler duygusal durumlardan kaçınma davranışı gösterirken, kadınlar bu durumlara yaklaşma eğilimindedir. Farklı araştırma sonuçları da bireylerin duygu tepkilerinin cinsiyete göre farklılık gösterdiğini ortaya koymaktadır (Nolen-Hoeksema ve Girgus, 1994; Fujita, Diener ve ark, 1991). Bu olasilıkların hepsini, bir duygu gereksinimi ölçeği kullanarak açıklamak mümkündür (Maio ve Esses, 2001).

\section{Literatür taraması}

Narsisizm, daha önce de değinildiği gibi kendine hayranlık besleme, kendini abartılı olarak sevme ile tanımlanan bir kişilik özelliğidir ve genel kanı narsisizmin özellikle 1980'lerden bu yana hızlı bir yükseliş eğilimine girmiş olduğudur. Narsisizm kişilik özelliklerinin hangi değişkenlerle ilişkili olduğunu bulgulamak için literatürde Beş Faktör kişilik modelinden yararlanıldığı görülmektedir. Bu bağlamda yapılan araştırmalar deneyime açıklık ve dışa dönüklük kişilik boyutlarının narsisizmi yüksek düzeylerde yordadığını, uyumluluk ile narsisizm arasında ise negatif korelasyon olduğunu göstermektedir. Diğer iki boyutta ise sorumluluk ile pozitif, duygusal denge ile de negatif yönde düşük korelesyonlar saptanmıştır. (Bradlee ve Emmons, 1992; Paulhus, 2001; Paulhus ve Williams, 2002; Ames, Rose ve Anderson, 2006; Vernon, Villani, Vickers ve Harris, 2008; Uçar ve Konal, 2017).

Gelişim dönemleri bağlamında yapılan araştırmalar ise narsisizm eğilimlerinin yaş değişkeni ile ilişkili olduğunu ortaya koymaktadır. Araştırmalardaki genel tablo, özellikle ergen gruplarındaki narsisizm eğilimlerinin yetişkin gruplara göre daha fazla olduğunu göstermektedir. Ergenlik, ergen benmerkezciliğinin etkisiyle benlik bilincinin yükseldiği bir dönem olarak değerlendirilmektedir. Bu dönemdeki birey, diğerlerinin onunla ne kadar ilgilendiği odağında, benzersizlik ve incinmezlik algısı ile gelişim dönemine özgü kendine yönelik bir tutum içindedir (Sant- 
rock, 2012. Bu da ergenin kendine aşırı güvenmesi, her şeyi yapabileceğini düşünmesi, kendisinin eşsiz ve biricik bir varlık olduğuna dair inanC1 (Steinberg, 2007) ile ilişkilendirilebilir. Carlson ve Gjerde (2009) tarafından yapılan boylamsal çalışmada narsisizmin özellikle 14-18 yaş aralığında belirgin şekilde arttı̆̆ bulgulanırken, 18-23 yaş aralığında ise hafif bir düşüş eğilimine girdiği gözlenmiştir. Bir diğer araştırmada ise 18-25 yaş aralığındaki beliren yetişkin (Arnett, 1997, 1998) grubundaki üniversite öğrencilerinin narsisizm skorlarının orta ve ileri yaş gruplarına göre anlamlı olarak yüksek olduğu bulgulanmıştır (Robert, Edmonds ve Grijalva, 2010). Türkiye'de yapılan araştırma sonuçlarının da bu çalışmalarla paralel sonuçlar verdiği görülmektedir. Akıncı'nın (2015) çalışmasında narsisizm eğilimlerinin yaş değişkenine bağlı olarak belirgin şekilde farklılaştığı; genç ve orta yetişkinlere göre beliren yetişkin grubunun yüksek puanlar aldığı görülmektedir. Ayrıca çalışma sonuçlarına göre yaşın ilerlemesiyle narsisizm puanlarının düşme çizgisinde olduğu vurgulanmaktadır. Özer Uğurluoğlu, Kahraman ve Avcı'ının (2016) çalışmasında da aynı doğrultuda sonuçlara varıldığı görülmektedir. Yaşın ilerlemesine bağlı olarak narsisizmdeki düşüş eğilimlerini insanların daha da olgunlaşmaları, kendilerini ve çevrelerini olduğu gibi kabul etmeleri ile ilişkilendirmek mümkün gözükmektedir (Güngör, Arıcak ve Ekşi, 2012).

Duygu gereksinimi, daha önce de değinildiği gibi insanların kendi duygularıyla diğerlerinin duygularını anlama arzusunu içerir. Belirli tutum ve davranışları açıklamada ise kişilik özelliklerinin belirleyici olduğu düşünülmektedir. Kişilik özellikleri ile duygu gereksinimi ilişkileri incelendiğinde Büyük Beşli kişilik özelliklerinden deneyime açıklık ve uyumluluk boyutlarının duygulara yaklaşma ile pozitif yönde anlamlı ilişkisi bulgulanmış, duygulardan kaçınma ile de duygusal denge, uyumluluk, deneyime açıklık ve sorumluluk boyutlarının negatif ilişkisi saptanmıştır (Maio ve Esses, 2001; Uçar, 2017). Duygu gereksinimi, yaş değişkeni bağlamında değerlendirildiğinde ise önemli ölçüde yaş ile negatif yönlü korelasyonu bulgulanmış, dolayısıyla yaşın ilerlemesi duygu gereksiniminin azaldığını göstermiştir (Maio ve Esses, 2001). 


\section{Amaç}

$\mathrm{Bu}$ araştırmanın temel amacl; yukarıda değinilen kuramsal tartışmalardan hareketle duygu gereksinimi, benlik saygısı ve kişiliğin dışa dönüklük, uyumluluk, duygusal denge, sorumluluk ve deneyime açıklık boyutlarının lise, üniversite ve ögrretmen gruplarında narsisizmi yordayıp yordamadığını araştırmaktır. Buna ek olarak duygu gereksinimi, benlik saygısı ve kişiliğin dışa dönüklük, uyumluluk, duygusal denge, sorumluluk ve deneyime açıklık boyutları ile narsisizm özelliklerinin lise, üniversite ve öğretmen grupları arasındaki eğilim farklılıklarını hem cinsiyet hem de genel bağlamda ortaya koymaktır. Bu amaç doğrultusunda araştırmada kuramsal açıklamalar dikkate alınarak bu değişkenleri içeren bir çoklu regresyon modeli kurulmuş ve test edilmiştir. Bu değişkenlerin gruplar arasında farklılaşıp farklılaşmadığını belirlemek için de tek yönlü varyans analizi ve $t$ testi uygulanmıştır. Araştırmanın soruları aşağıda sunulmuştur:

Lise, üniversite ve öğretmen gruplarında dışa dönüklük, uyumluluk, duygusal denge, sorumluluk ve deneyime açıklık; duygulara yaklaşma ve duygulardan kaçınma ile benlik saygısı ve narsisizmi anlamlı olarak yordamakta midır?

Dışa dönüklük, uyumluluk, duygusal denge, sorumluluk ve deneyime açıklık; duygulara yaklaşma ve duygulardan kaçınma ile benlik saygisı ve narsisizm toplam puan ortalamaları; lise, üniversite ve öğretmen grupları arasında anlamlı olarak farklılaşmakta mıdır?

Kadın ve erkeklerde dışa dönüklük, uyumluluk, duygusal denge, sorumluluk ve deneyime açıklık; duygulara yaklaşma ve duygulardan kaçınma ile benlik saygısı ve narsisizm toplam puan ortalamaları anlamlı olarak farklılaşmakta mıdır?

\section{Yöntem}

Araştırma, var olan durumu ortaya koyan betimsel bir araştırmadır. Türkiye'de lise, üniversite ve yetişkinlik döneminde dişa dönüklük, uyumluluk, duygusal denge, sorumluluk, deneyime açılık kişilik boyutlarıyla duygulara yaklaşma, duygulardan kaçınma ve benlik saygisı ile narsisizm arasındaki ilişkileri incelemek amacıyla ilişkisel tarama 
modeline dayanan bir araştırma gerçekleştirilmiştir. Tarama modelleri, geçmişte ya da halen var olan bir durumu var olduğu şekliyle betimlemeyi amaçlayan araştırma yaklaşımlarıdır (Karasar, 2004). Veriler, farklı yaşlardaki bireylerden elde edilmiş ve kesitsel araştırma düzeni kullanılmıştır. Araştırmada lise, üniversite öğrencileri ve öğretmenlik yapan grup üzerinde kişiliğin dişa dönüklük, uyumluluk, duygusal denge, sorumluluk ve deneyime açılık boyutları ile benlik saygısı ve narsisizm üzerindeki ilişkilerini içeren çoklu bir regresyon modeli geliştirilip test edilmiştir.

\section{Çalışma grubu}

Katılımcılar Niğde ilinde öğrenim gören özel bir temel lise öğrencileri, Aksaray Üniversitesinde eğitim alan öğrenciler ve Niğde ilinde Lisede çalışan orta öğretim kademesindeki öğretmenlerden oluşmaktadır. Ölçme araçlarının uygulanacağı bireylerin, "18-40 yaş aralığında (ergenlik, beliren yetişkinlik ve yetişkinlik döneminde) olması" durumu dikkate alınarak araştırma için amaçlı (purposive) örnekleme yöntemlerinden maksimum çeşitlilik yöntemi belirlenmiştir.

Amaçlı örneklemde araştırmacı, evrenle ilgili daha önceki kuramsal bilgilere, kendi bilgilerine ve araştırmanın özel amacına dayanarak bir örneklem belirlemektedir (Fraenkel ve Wallen ve Huyn, 1993). Bu örneklemenin temeli, araştırmanın amaçları doğrultusunda bir evrenin temsilci bir örneği yerine, amaçlı olarak bir ya da birkaç alt kesimini örnek olarak alıp evrenin araştırma problemine en uygun olanını gözlem konusu yapmaktır. Bu örnekleme yönteminin evren değerleri hakkında önemli ipuçları vereceği ifade edilmektedir (Büyüköztürk, Kılıç Çakmak, Akgün, Karadeniz ve Demirel, 2008).

Çalışma grubu, Aksaray ilinde 2016-2017 yılında öğrenim görmekte olan 267 lisans öğrencisi ile Niğde ilindeki 88 öğretmen ve 509 lise öğrencisinden oluşmaktadır. Araştırma kapsamında kullanılan veri toplama araçları 864 katılımcıya uygulanmıştır. Uç değerler temizlendikten sonra çalışma, 183 Rehberlik ve Psikolojik Danışmanlık (\%22.2), 31 FenEdebiyat Fakültesi Matematik Bölümü (\%3.8), 45 Fen-Edebiyat Fakültesi Sosyoloji Bölümü (\%5.4) olmak üzere toplam 259 üniversite öğrencisi (\%31.4) ile Niğde ilinde öğrenim görmekte olan 43 lise 9. sinıf (\%5.2), 46 
lise10. sinıf (\%5.6), 127 lise 11. sinıf (\%15.3), 264 lise 12. sınıf (\%32) toplam 479 lise öğrencisi (\%58.2) ve Niğde ilinde çalışan 88 (\%10.7) öğretmen olmak üzere toplam 826 kişiden oluşan katılımcı üzerinde analizler yapılmıştır.

Çalışma grubunun 506'sı kadın (\%61.3), 320'si erkektir (\%38.7). Çalışma grubunun yaşları ise 18 ile 41 arasında değişmektedir ( yaş=19.63; Sd: 4.17).

\section{Veri toplama araçları}

\section{Hızlı büyük beşli kişilik ölçeği}

Kişilik özelliklerini ölçmek amacıyla Goldberg'ìn (1992) ortaya koyduğu kişilik özellikleri ile ilgili 100 sıfattan, Vermulst ve Gerris (2005) tarafından 30'u seçilerek geliştirilen ve Morsünbül (2014) tarafından Türkçe uyarlaması yapılan Hızlı Büyük Beşli Kişilik ölçeği kullanılmıştır. Testte her bir kişilik özelliği 6 madde ile ölçülmektedir. Maddeler, "tamamen doğru" dan (7 puan), "tamamen yanlış" a (1 puan) doğru sıralanan likert tipi 7 derecelendirmeli bir değerlendirme ölçeği üzerinde işaretlenmektedir. Hızlı Büyük Beşli Kişilik ölçeğinin cronbach alfa iç güvenirliği katsayısı .70 olarak bulunmuştur. Bu araştırmada cronbach alfa katsayısı; dışa dönüklük alt boyutu için .80 , uyumluluk alt boyutu için .68 , sorumluluk alt boyutu için .81, duygusal denge alt boyutu için .68, deneyime açıklık alt boyutu içinse .65 olarak bulunmuştur.

\section{Benlik saygısı ölçeği}

Benlik saygısını ölçmek amacı ile Rosenberg (1965) tarafından geliştirilen benlik saygısı ölçeğinin 10 maddelik kısa formu kullanılmıştır. Ölçeğin Türkçeye uyarlanması Çuhadaroglu, (1986) tarafından yapılmıştır. Maddeler 1 ve 4 arasında puanlanmaktadır. Ölçekten alınan yüksek puan benlik saygısının fazla olduğunu, düşük puan ise benlik saygısının düşük olduğunu göstermektedir. Bu çalışmada ölçeğin cronbach alfa iç tutarlılık katsayısı .86 olarak bulunmuştur. 
Öğretmenler ile Lise ve Üniversite Öğrencilerindeki Narsisizm Kişilik Özellikleri Benlik Saygısı ve Duygu Gereksinimi Arasındaki İlişkiler

\section{Narsisizm ölçeği}

Narsisizm puanlarını ölçmek amacıyla Raskin ve Terry'nin (1988) geliştirdiği 40 maddelik narsisizm envanterinin Ames, Rose ve Anderson (2006) tarafından kısaltılarak 16 maddeye indirgenen kısa formu kullanılmıştır. Ölçeğin Güngör ve Selçuk'un (2015) çalışmalarıyla Türkçeye uyarlanan versiyonu tercih edilmiştir. Ölçeğin uygulanmasında katılımcılardan iki önermeden oluşan her bir madde için kendisini yakın hissettiği önermenin işaretlenmesi istenmektedir. $\mathrm{Bu}$ araştırmada ölçeğin cronbach alfa değeri .70 olarak bulunmuştur.

Duygu gereksinimi ölçeği kısa formu: Apple, Gnambs ve Maio tarafından kısa formu geliştirilmiş olan Duygu Gereksinimi Ölçeği'nin Türkçe uyarlaması Uçar (2017) tarafından yapılmıştır. Ölçek 10 maddeden oluşan 5 dereceli likert tipi bir ölçektir. 5 madde duygulara yaklaşmayı, 5 madde duygulardan kaçınmayı ölçmektedir. Bu araştırmada duygulara yaklaşma alt ölçeğin cronbach alfa değeri .78, duygulardan kaçınma alt boyutunun cronbach alfa değeri ise .73 olarak bulunmuştur.

\section{Süreç}

Araştırmada veriler, bireysel uygulama ve grup uygulaması şeklinde toplanmıştır. Veriler, ders saatleri içinde dersin yürütücüsünün izni ve yardımıyla elde edilmiştir. Ölçeklerin uygulanması 20-25 dakika arasında değişmiştir. Araştırma verileri Aksaray ve Niğde illerinde Nisan 2017- Mayıs 2017 tarihleri arasında toplanmıştır. Veriler toplanırken gönüllülük ilkesi esas alınmış, katılımcılara öncelikle araştırmanın amacına yönelik kısa bir bilgi verilmiş ve ardından araştırmaya katılmak isteyen katılımclara ölçekler dağıtılmıştır. Ayrıca, gerekli durumlarda katılımc1lara ek açıklamalar yapılmış, katılımcılardan kimlik bilgileri istenmemiştir.

\section{Bulgular}

Katılımcıların ölçeklerden aldıkları puanlara ait aritmetik ortalamalar 
aşağıda sunulmuştur:

Tablo 1: Betimsel İstatistikler

\begin{tabular}{|c|c|c|c|c|c|c|c|}
\hline & & $\mathrm{N}$ & $\overline{\bar{X}}$ & Ss & Çarpıklık & Basıklık & Ranj \\
\hline \multirow{9}{*}{ D. } & Narsisizm & 259 & 5.11 & 2.84 & .480 & -.094 & 13.00 \\
\hline & Benlik saygısı & 259 & 31.56 & 5.15 & -.374 & -.263 & 23.00 \\
\hline & Uyumluluk & 259 & 33.39 & 4.52 & -.225 & -.195 & 22.00 \\
\hline & Dişa dönüklük & 259 & 23.91 & 6.53 & .207 & -.204 & 36.00 \\
\hline & Sorumluluk & 259 & 29.19 & 6.80 & -.370 & -.322 & 33.00 \\
\hline & Duygusal denge & 259 & 22.82 & 5.83 & .211 & -.270 & 30.00 \\
\hline & Deneyime açıklık & 259 & 30.44 & 4.70 & -.014 & -.668 & 21.00 \\
\hline & Duygu yaklaşma & 259 & 20.03 & 3.06 & -.440 & .224 & 15.00 \\
\hline & Duygu kaçınma & 259 & 12.00 & 3.95 & .229 & -.124 & 19.00 \\
\hline \multirow{9}{*}{ Oڤّ } & Narsisizm & 88 & 5.36 & 2.89 & .432 & -.311 & 12.00 \\
\hline & Benlik saygısı & 88 & 33.19 & 4.47 & -.328 & -.633 & 18.00 \\
\hline & Uyumluluk & 88 & 35.11 & 4.29 & -.586 & .033 & 20.00 \\
\hline & Dişa dönüklük & 88 & 25.81 & 7.13 & .113 & -.647 & 30.00 \\
\hline & Sorumluluk & 88 & 31.43 & 6.98 & -.525 & .007 & 33.00 \\
\hline & Duygusal denge & 88 & 24.13 & 6.20 & .340 & -.051 & 29.00 \\
\hline & Deneyim açıklık & 88 & 32.13 & 5.22 & -.228 & -.688 & 23.00 \\
\hline & Duygu yaklaşma & 88 & 20.01 & 3.04 & -.509 & .814 & 15.00 \\
\hline & Duygu kaçınma & 88 & 11.84 & 4.03 & .515 & -.174 & 18.00 \\
\hline \multirow{9}{*}{$\stackrel{\varpi}{\varpi}$} & Narsisizm & 479 & 6.93 & 3.16 & .223 & -.388 & 15.00 \\
\hline & Benlik saygısı & 479 & 30.54 & 5.58 & -.518 & -.129 & 26.00 \\
\hline & Uyumluluk & 479 & 33.48 & 4.58 & -.338 & -.369 & 22.00 \\
\hline & Dişa dönüklük & 479 & 25.36 & 7.71 & -.107 & -.535 & 36.00 \\
\hline & Sorumluluk & 479 & 27.49 & 7.11 & -.262 & -.494 & 33.00 \\
\hline & Duygusal denge & 479 & 23.51 & 5.93 & .108 & -.426 & 32.00 \\
\hline & Deneyim açıklık & 479 & 31.40 & 5.12 & -.198 & -.353 & 26.00 \\
\hline & Duygu yaklaşma & 479 & 20.09 & 3.3 & -.468 & -.448 & 14.00 \\
\hline & Duygu kaçınma & 479 & 12.19 & 4.42 & .596 & -.141 & 20.00 \\
\hline
\end{tabular}


Öğretmenler ile Lise ve Üniversite Öğrencilerindeki Narsisizm Kişilik Özellikleri Benlik Saygısı ve Duygu Gereksinimi Arasındaki İlişkiler

Tablo 2: Dışa dönüklük, uyumluluk, duygusal denge, sorumluluk, deneyime açıklık, duygulara yaklaşma, duygulardan kaçınma ve benlik saygısı ile narsisizm arasındaki ilişkiler

\begin{tabular}{|c|c|c|c|c|c|c|c|c|c|c|}
\hline & & 1 & 2 & 3 & 4 & 5 & 6 & 7 & 8 & 9 \\
\hline \multirow{9}{*}{ 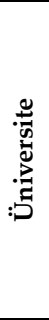 } & 1.Narsisizm & 1 & $.287^{* *}$ & $.123^{*}$ & .116 & .092 & -.072 & $.320^{* *}$ & .113 & .006 \\
\hline & 2.Benlik saygısı & & 1 & $.425^{* *}$ & $.230^{* *}$ & $.308^{* *}$ & $.284^{* *}$ & $.347^{* *}$ & $.196^{* *}$ & $-.440^{* *}$ \\
\hline & 3.Uyumluluk & & & 1 & .110 & $.463^{* *}$ & .073 & $.481^{* *}$ & $.340^{* *}$ & $-.211^{* *}$ \\
\hline & 4.Dışa dönüklük & & & & 1 & -.046 & $.311^{* *}$ & $.188^{* *}$ & .016 & -.081 \\
\hline & 5.Sorumluluk & & & & & 1 & .024 & $.243^{* *}$ & $.152^{*}$ & $-.230^{* *}$ \\
\hline & 6.Duygusal denge & & & & & & 1 & .044 & $-.178^{* *}$ & $-.290^{* *}$ \\
\hline & 7.Deneyimeaçıklık & & & & & & & 1 & $.268^{* *}$ & $-.140^{*}$ \\
\hline & 8.Duyguyaklaşma & & & & & & & & 1 & -.073 \\
\hline & 9.Duygukaçınma & & & & & & & & & 1 \\
\hline \multirow{9}{*}{ 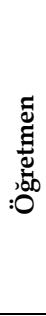 } & 1Narsisizm & 1 & .200 & .104 & .208 & .151 & .041 & $.394^{* *}$ & .095 & -.087 \\
\hline & 2Benlik saygısı & & 1 & $.309^{* *}$ & $.382^{* *}$ & $.263^{*}$ & $.417^{* *}$ & $.296^{* *}$ & .093 & $-.384^{* *}$ \\
\hline & 3 Uyumluluk & & & 1 & .200 & $.279^{* *}$ & $.277^{* *}$ & $.414^{* *}$ & $.272^{*}$ & $-.230^{*}$ \\
\hline & 4 Dışa dönüklük & & & & 1 & -.010 & .207 & $.331^{* *}$ & .102 & $-.252^{*}$ \\
\hline & 5 Sorumluluk & & & & & 1 & $.345^{* *}$ & $.243^{*}$ & .045 & -.046 \\
\hline & 6Duygusal denge & & & & & & 1 & $.371^{* *}$ & -.002 & $-.344^{* *}$ \\
\hline & 7Deneyimeaçıklık & & & & & & & 1 & $.249^{*}$ & $-.313^{* *}$ \\
\hline & 8Duyguyaklaşma & & & & & & & & 1 & -.011 \\
\hline & 9Duygukaçınma & & & & & & & & & 1 \\
\hline \multirow{9}{*}{$\stackrel{\mathscr{\varpi}}{.}$} & 1Narsisizm & 1 & $.289^{* *}$ & .036 & $.304^{* *}$ & -.051 & .068 & $.285^{* *}$ & .034 & -.041 \\
\hline & 2Benlik saygisı & & 1 & $.173^{* *}$ & $.207^{* *}$ & $.166^{* *}$ & $.328^{* *}$ & $.138^{* *}$ & .000 & $-.330^{* *}$ \\
\hline & 3 Uyumluluk & & & 1 & $.093^{*}$ & $.281^{* *}$ & .008 & $.336^{* *}$ & $.243^{* *}$ & -.089 \\
\hline & 4 Dişa dönüklük & & & & 1 & $-.150^{* *}$ & $.386^{* *}$ & $.140^{* *}$ & .005 & $-.182^{* *}$ \\
\hline & 5 Sorumluluk & & & & & 1 & .019 & $.095^{*}$ & .052 & -.044 \\
\hline & 6Duygusal denge & & & & & & 1 & .014 & $-.135^{* *}$ & $-.280^{* *}$ \\
\hline & 7Deneyimeaçıklık & & & & & & & 1 & $.204^{* *}$ & -.022 \\
\hline & 8Duyguyaklaşma & & & & & & & & 1 & $-.104^{*}$ \\
\hline & 9Duygukaçınma & & & & & & & & & 1 \\
\hline
\end{tabular}

${ }^{* *} \mathrm{p}<0.01{ }^{*} \mathrm{p}<0.05$

Tablo 3: Dışa dönüklük, uyumluluk, duygusal denge, sorumluluk, deneyime açıklik kişilik boyutlarn ile benlik saygısı, duygulara yaklaşma ve duygulardan kaçınmanın öğretmen, lise ve üniversite grubunda narsisizmi yordayıp yordamadı̆̆ına ilişkin regresyon analizi

\begin{tabular}{lllllllllll}
\hline & Model & $\mathrm{B}$ & $\begin{array}{l}\text { Sd. } \\
\text { hata }\end{array}$ & $\beta$ & $\mathrm{t}$ & $\mathrm{p}$ & $\mathrm{R}$ & $\mathrm{R}^{2}$ & $\mathrm{~F}$ & $\mathrm{P}$ \\
\hline Üniversite & Sabit & - & 2,043 &, $432^{\mathrm{a}}$ & - & .114 &, $432^{\mathrm{a}}$ &, 186 & 7,151 &, 000 \\
& & 3,244 & & & 1,588 & & & & & \\
\hline Öğretmen & Sabit & - & 3,787 &, $454^{\mathrm{b}}$ &,- 819 &, 415 &, $454^{\mathrm{b}}$ &, 206 & 2,564 &, 015 \\
& & 3,100 & & & & & & & & \\
\hline Lise & Sabit & - & 1,598 &, $472^{\mathrm{c}}$ & - & .261 &, $472^{\mathrm{c}}$ &, 223 & 16,822 &, 000 \\
& & 1,799 & & & 1.126 & & & & & \\
\hline
\end{tabular}

Dışa dönüklük, uyumluluk, duygusal denge, sorumluluk, deneyime 
açıklık kişilik özellikleri, duygulara yaklaşma, duygulardan kaçınma ve benlik saygısının narsisizmi üniversite öğrencilerinde yordayıp yordamadığına ilişkin çoklu regresyon analizi yapılmıştır. Yapılan analiz sonucunda VIF değeri 1.61 olarak bulunmuştur. VIF değerinin 10.00 'dan küçük olması, değişkenler arasında otokorelasyon olmadığını, bu nedenle regresyon analizinin yapılabileceğini göstermektedir. Regresyon analizi sonuçlarına göre dışa dönüklük, uyumluluk, duygusal denge, sorumluluk, deneyime açıklık kişilik boyutları ile duygulara yaklaşma, duygulardan kaçınma ve benlik saygısının narsisizmi üniversite öğrenci-

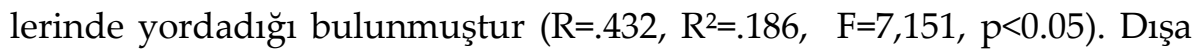
dönüklük, uyumluluk, duygusal denge, sorumluluk, deneyime açılık, duygulara yaklaşma, duygulardan kaçınma ve benlik saygısının, narsisizm ortalamalarına ilişkin toplam varyansın \% 19'unu açıkladığı görülmektedir.

Dışa dönüklük, uyumluluk, duygusal denge, sorumluluk, deneyime açıklık kişilik özellikleri ile duygulara yaklaşma, duygulardan kaçınma ve benlik saygısının narsisizmi öğretmenlerde yordayıp yordamadığına ilişkin çoklu regresyon analizi yapılmıştır. Yapılan analiz sonucunda VIF değeri 1.52 olarak bulunmuştur. Regresyon analizi sonuçlarına göre dişa dönüklük, uyumluluk, duygusal denge, sorumluluk, deneyime açılık, duygulara yaklaşma, duygulardan kaçınma ve benlik saygısının, narsisizmi öğretmenlerde yordadığı bulunmuştur $\left(R=.454, R^{2}=.206, F=2,564\right.$, $\mathrm{p}<0.01)$. Dişa dönüklük, uyumluluk, duygusal denge, sorumluluk, deneyime açıklık, duygulara yaklaşma, duygulardan kaçınma ve benlik saygısının narsisizm ortalamalarına ilişkin toplam varyansın \%20'sini açıladığı görülmektedir.

Dişa dönüklük, uyumluluk, duygusal denge, sorumluluk, deneyime açıklık kişilik özellikleri ile duygulara yaklaşma, duygulardan kaçınma ve benlik saygısının narsisizmi lise öğrencilerinde yordayıp yordamadığına ilişkin çoklu regresyon analizi yapılmıştır. Yapılan analiz sonucunda VIF değeri 1.27 olarak bulunmuştur. Bu değer değişkenler arasında otokorelasyon olmadığını bu nedenle regresyon analizinin yapılabileceğini göstermektedir. Regresyon analizi sonuçlarına göre dişa dönüklük, uyumluluk, duygusal denge, sorumluluk, deneyime açılık, duygulara yaklaşma, duygulardan kaçınma ve benlik saygısının, narsisizmi lise öğrencilerinde yordadığ 1 bulunmuştur $\left(\mathrm{R}=.472, \quad \mathrm{R}^{2}=.223, \quad \mathrm{~F}=16.822\right.$, 
Öğretmenler ile Lise ve Üniversite Öğrencilerindeki Narsisizm Kişilik Özellikleri Benlik Saygısı ve Duygu Gereksinimi Arasındaki İlişkiler

$\mathrm{p}<0.05)$. Dişa dönüklük, uyumluluk, duygusal denge, sorumluluk, deneyime açıklık, duygulara yaklaşma, duygulardan kaçınma ve benlik saygısının narsisizm ortalamalarına ilişkin toplam varyansın \% 22'sini açıkladığ1 görülmektedir.

Tablo 4: Benlik saygısı, dışa dönüklük, uyumluluk, duygusal denge, sorumluluk, deneyime açıklık kişilik özellikleri, duygulara yaklaşma ve duygulardan kaçınmanın, narsisizmi öğretmen, lise ve üniversite grubunda yordayıp yordamadığına ilişkin regresyon katsayisı tablosu

\begin{tabular}{|c|c|c|c|c|c|c|c|c|c|}
\hline & Model & B & Sd.hata & $\beta$ & $t$ & $\mathbf{P}$ & İkili & Kismı & VIF \\
\hline \multirow{9}{*}{ D: } & Sabit & -3.244 & 2.043 & & -1.588 & .114 & & & \\
\hline & Benlik Saygısı & .178 & .040 & .323 & 4.458 & .000 & .271 & .254 & 1.610 \\
\hline & Uyumluluk & -.078 & .047 & -.125 & -1.654 & .099 & -.104 & -.094 & 1.744 \\
\hline & Dışa dönüklük & .027 & .027 & .061 & .990 & .323 & .062 & .056 & 1.185 \\
\hline & Sorumluluk & .008 & .028 & .020 & .301 & .764 & .019 & .017 & 1.344 \\
\hline & Duygusal denge & -.073 & .032 & -.150 & -2.301 & .022 & -.144 & -.131 & 1.308 \\
\hline & Deneyim açıklık & .167 & .041 & .277 & 4.113 & .000 & .252 & .235 & 1.391 \\
\hline & Duyguyaklaşma & -.003 & .059 & -.003 & -.049 & .961 & -.003 & -.003 & 1.223 \\
\hline & Duygukaçınma & .091 & .047 & .127 & 1.938 & .054 & .122 & .111 & 1.315 \\
\hline \multirow{9}{*}{ 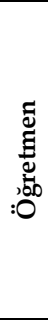 } & Sabit & -3.100 & 3.787 & & -.819 & .415 & & & \\
\hline & Benlik Saygısı & .089 & .080 & .137 & 1.108 & .271 & .124 & .111 & 1.526 \\
\hline & Uyumluluk & -.065 & .079 & -.097 & -.827 & .410 & -.093 & -.083 & 1.369 \\
\hline & Dişa dönüklük & .034 & .046 & .084 & .741 & .461 & .083 & .074 & 1.293 \\
\hline & Sorumluluk & .044 & .047 & .107 & .946 & .347 & .106 & .095 & 1.269 \\
\hline & Duygusal denge & -.088 & .057 & -.188 & -1.547 & .126 & -.171 & -.155 & 1.467 \\
\hline & Deneyim açıklık & .235 & .068 & .424 & 3.448 & .001 & .362 & .346 & 1.505 \\
\hline & Duyguyaklaşma & -.010 & .101 & -.011 & -.100 & .921 & -.011 & -.010 & 1.137 \\
\hline & Duygukaçınma & .026 & .082 & .037 & .320 & .750 & .036 & .032 & 1.318 \\
\hline \multirow{9}{*}{ 忽 } & Sabit & -1.799 & 1.598 & & -1.126 & .261 & & & \\
\hline & Benlik Saygısı & .160 & .026 & .282 & 6.133 & .000 & .272 & .249 & 1.278 \\
\hline & Uyumluluk & -.070 & .032 & -.102 & -2.207 & .028 & -.101 & -.090 & 1.283 \\
\hline & Dişa dönüklük & .110 & .019 & .268 & 5.836 & .000 & .260 & .237 & 1.276 \\
\hline & Sorumluluk & -.021 & .019 & -.048 & -1.087 & .278 & -.050 & -.044 & 1.160 \\
\hline & Duygusal denge & -.060 & .025 & -.112 & -2.370 & .018 & -.109 & -.096 & 1.354 \\
\hline & Deneyim açıklık & .154 & .027 & .250 & 5.663 & .000 & .253 & .230 & 1.177 \\
\hline & Duyguyaklaşma & .000 & .040 & .000 & .007 & .994 & .000 & .000 & 1.129 \\
\hline & Duygukaçınma & .046 & .032 & .064 & 1.438 & .151 & .066 & .058 & 1.197 \\
\hline
\end{tabular}

Üniversite öğrencilerinde narsisizmi benlik saygısı, kişilik boyutları ve duygu gereksiniminin yordayıp yordamadığına ilişkin çoklu regresyon analizindeki $\beta$ değerleri incelendiğinde benlik saygısının narsisizm toplam puan ortalamalarına ilişkin varyansın \%32'sini açıkladığ görülmektedir $(\beta=.323, \mathrm{t}=4.458, \mathrm{p}<0.05)$. Kişilik boyutlarından ise deneyime açıklık, narsisizm toplam puan ortalamalarına ilişkin varyansın \%28'ini 
açıklarken $(\beta=.277, \mathrm{t}=4.113, \mathrm{p}<.05)$ duygusal denge kişilik boyutu ise narsisizm toplam puan ortalamalarına ilişkin varyansın \%15'ini açıklamaktadır $(\beta=-.150, t=-2.301, p<0.05)$. Ancak duygusal denge boyutunda değerler negatif yöndedir. Buradan hareketle duygusal denge arttıkça narsisizmin azaldığı yorumu yapılabilir.

Öğretmenlerde narsisizmi benlik saygısı, kişilik boyutları ve duygu gereksinimin yordayıp yordamadığına ilişkin çoklu regresyon analizindeki $\beta$ değerleri incelendiğinde, yalnızca deneyime açıklık kişilik boyutunun narsisizm toplam puan ortalamalarına ilişkin varyansın $\% 42$ 'sini açıkladığı görülmektedir $(\beta=.424, \mathrm{t}=3.448, \mathrm{p}<0.05)$.

Lise öğrencilerinde narsisizmi benlik saygısı, kişilik boyutları ve duygu gereksinimin yordayıp yordamadığına ilişkin çoklu regresyon analizindeki $\beta$ değerleri incelendiğinde benlik saygısının narsisizm toplam puan ortalamalarına ilişkin varyansın \%28'ini açıkladığ görülmektedir $(\beta=.282, \mathrm{t}=6.133, \mathrm{p}<.05)$. Dişa dönüklük kişilik boyutu, narsisizm toplam puan ortalamalarına ilişkin varyansın $\% 27$ 'isi açıklarken $(\beta=.268, t=5.836$, $\mathrm{p}<.05)$, deneyime açıklık kişilik boyutunun ise narsisizm toplam puan ortalamalarına ilişkin varyansın \%25'ini açıladığı görülmektedir $(\beta=$ $.250, t=5.663, p<.05)$. Duygusal denge kişilik boyutunun ise narsisizm toplam puan ortalamalarına ilişkin varyansın \%11'ini açıkladığı görülmektedir $(\beta=-.112, \mathrm{t}=-2.370, \mathrm{p}<.05)$. Ancak duygusal denge boyutundaki değerler negatif yöndedir ve buradan hareketle lise öğrencilerinde de duygusal denge arttıkça narsisizmin azaldığı yorumu yapılabilir.

Yapılan varyans analizi sonuçlarına göre narsisizm puan ortalamalarında öğretmen, üniversite ve lise öğrencileri arasında anlamlı bir farklılik bulunmuştur $(\mathrm{F}=33.764, \mathrm{p}<0.05)$. Scheffe testi sonuçlarına göre de farklılık, lise ve üniversite öğrenci gruplarıyla $\left(\overline{\mathrm{X}}_{\text {lise }}=6.93, \overline{\mathrm{X}}_{\text {üniv }}=5.11\right.$, I-J= 1.81) lise ve öğretmen gruplarına ilişkin sonuçlarda anlamlı olarak gözükmektedir $\left(\overline{\mathrm{X}}_{\text {lise }}=6.93, \overline{\mathrm{X}}_{\text {ŏğretmen}}=5.36, \mathrm{I}-\mathrm{J}=1.56\right)$. Benlik sayg1Sı puan ortalamaları incelendiğinde puanlar, öğretmen ve üniversite $\left(\overline{\mathrm{X}}_{\text {ögretmen }}=33.19\right.$, $\left.\overline{\mathrm{X}}_{\text {üniversite }}=31.56, \mathrm{I}-\mathrm{J}=1.62\right)$, öğretmen ve lise $\left(\overline{\mathrm{X}}_{\ddot{\text { ğgretmen }}}=33.19, \overline{\mathrm{X}}_{\text {ise }}=30.54, \mathrm{I}-\mathrm{J}=\right.$ 2.64), lise ve üniversite ( $\overline{\mathrm{X}}_{\text {üniversite }}=31.56, \overline{\mathrm{X}}_{\text {lise }}=30.54$, I-J= 1.01) grupları arasinda yine anlamlı bir farklılığa işaret etmektedir. 
Öğretmenler ile Lise ve Üniversite Öğrencilerindeki Narsisizm Kişilik Özellikleri Benlik Saygısı ve Duygu Gereksinimi Arasındaki İlişkiler

Tablo 5: Öğretmen lise ve üniversite gruplarında narsisizm, benlik saygısı, dışa dönüklük, uyumluluk, duygusal denge, sorumluluk, deneyime açıklık kişilik özellikleri, duygulara yaklaşma ve duygulardan kaçınma puan ortalamalarına ilişkin anova tablosu

\begin{tabular}{|c|c|c|c|c|c|c|c|}
\hline & & KT & $\mathrm{sd}$ & $\mathrm{KO}$ & $\mathrm{F}$ & $\mathrm{p}$ & $\begin{array}{l}\text { Anlamli } \\
\text { fark }\end{array}$ \\
\hline \multirow{3}{*}{$\begin{array}{l}\text { Narsi- } \\
\text { sizm }\end{array}$} & Gruplar arası & 623.477 & 2 & 311.738 & \multirow[t]{3}{*}{33.764} & \multirow[t]{3}{*}{.000} & \multirow{3}{*}{$\begin{array}{l}\text { Üniv-lise. } \\
\text { öğret-lise }\end{array}$} \\
\hline & Grup içi & 7598.751 & 823 & 9.233 & & & \\
\hline & Toplam & 8222.228 & 825 & & & & \\
\hline \multirow{3}{*}{$\begin{array}{l}\text { Benlik } \\
\text { Sayg1sı }\end{array}$} & Gruplar arası & 585.873 & 2 & 292.936 & \multirow[t]{3}{*}{10.260} & \multirow[t]{3}{*}{.000} & \multirow{3}{*}{$\begin{array}{l}\text { Lise-üniv. } \\
\text { Lise-öğret }\end{array}$} \\
\hline & Grup içi & 23498.108 & 823 & 28.552 & & & \\
\hline & Toplam & 24083.981 & 825 & & & & \\
\hline \multirow{3}{*}{$\begin{array}{l}\text { Uyumlu- } \\
\text { luk }\end{array}$} & Gruplar arası & 218.897 & 2 & 109.449 & \multirow[t]{3}{*}{5.318} & \multirow[t]{3}{*}{.005} & \multirow{3}{*}{$\begin{array}{l}\text { Öğrr-lise } \\
\text { öğr-üniv }\end{array}$} \\
\hline & Grup içi & 16938.255 & 823 & 20.581 & & & \\
\hline & Toplam & 17157.153 & 825 & & & & \\
\hline \multirow{3}{*}{$\begin{array}{l}\text { Dişa } \\
\text { dönük- } \\
\text { lük }\end{array}$} & Gruplar arası & 427.943 & 2 & 213.972 & \multirow[t]{3}{*}{4.015} & \multirow[t]{3}{*}{.018} & \multirow[t]{3}{*}{ Üniv-lise } \\
\hline & Grup içi & 43860.817 & 823 & 53.294 & & & \\
\hline & Toplam & 44288.760 & 825 & & & & \\
\hline \multirow{3}{*}{$\begin{array}{l}\text { Sorumlu- } \\
\text { luk }\end{array}$} & Gruplar arası & 1367.792 & 2 & 683.896 & \multirow[t]{3}{*}{13.946} & \multirow[t]{3}{*}{.000} & Öğr-üniv. \\
\hline & Grup içi & 40360.256 & 823 & 49.040 & & & öğret-lise \\
\hline & Toplam & 41728.048 & 825 & & & & \\
\hline \multirow{3}{*}{$\begin{array}{l}\text { Duygu- } \\
\text { sal denge }\end{array}$} & Gruplar arası & 140.096 & 2 & 70.048 & \multirow[t]{3}{*}{1.990} & \multirow[t]{3}{*}{.137} & \\
\hline & Grup içi & 28973.755 & 823 & 35.205 & & & \\
\hline & Toplam & 29113.851 & 825 & & & & \\
\hline \multirow{3}{*}{$\begin{array}{l}\text { Deneyi- } \\
\text { me } \\
\text { açıklık }\end{array}$} & Gruplar arası & 245.613 & 2 & 122.807 & \multirow[t]{3}{*}{4.896} & \multirow[t]{3}{*}{.008} & Öğrr-üniv. \\
\hline & Grup içi & 20645.226 & 823 & 25.085 & & & Lise-üniv \\
\hline & Toplam & 20890.839 & 825 & & & & \\
\hline \multirow{3}{*}{$\begin{array}{l}\text { Duygu } \\
\text { yaklaşma }\end{array}$} & Gruplar arası & .937 & 2 & .468 & \multirow[t]{3}{*}{.044} & \multirow[t]{3}{*}{.957} & \\
\hline & Grup içi & 8708.991 & 823 & 10.582 & & & \\
\hline & Toplam & 8709.927 & 825 & & & & \\
\hline \multirow{3}{*}{$\begin{array}{l}\text { Duygu } \\
\text { kaçınma }\end{array}$} & Gruplar arası & 12.549 & 2 & 6.275 & \multirow[t]{3}{*}{.348} & \multirow[t]{3}{*}{.706} & \\
\hline & Grup içi & 14835.311 & 823 & 18.026 & & & \\
\hline & Toplam & 14847.860 & 825 & & & & \\
\hline
\end{tabular}

Kişilik boyutları değerlendirildiğinde ise uyumluluk kişilik boyutunda öğretmen ve lise ( $\overline{\mathrm{X}}_{\text {ŏgretmen }}=35.11, \overline{\mathrm{X}}_{\text {lise }}=33.48, \mathrm{I}-\mathrm{J}=1.63$ ), öğretmen ve üniversite $\left(\overline{\mathrm{X}}_{\ddot{o g ̆ r e t m e n ~}}=35.11, \overline{\mathrm{X}}_{\text {üniversite }}=33.39, \mathrm{I}-\mathrm{J}=-1.71\right.$ ) grupları arasında anlamlı bir fark ortaya çıkmıştır. Dışa dönüklük kişilik boyutunda üniversite ve lise grupları arasında anlamlı fark bulunmuştur $\left(\overline{\mathrm{X}}_{\text {lise }}=25.36\right.$, $\left.\bar{X}_{\text {üniv }}=23.91, \mathrm{I}-J=-1.45\right)$. Sorumluluk kişilik boyutunda öğretmen ve üniversite öğrencileri arasında $\left(\overline{\mathrm{X}}_{\text {ŏğretmen }}=31.43, \overline{\mathrm{X}}_{\text {üniversite }}=29.19, \mathrm{I}-\mathrm{J}=-2.23\right)$, öğretmen ve lise ( $\overline{\mathrm{X}} \ddot{\mathrm{g} g ̆ \text { retmen }}=31.43, \overline{\mathrm{X}}$ lise $=27.49, \mathrm{I}-\mathrm{J}=3.94$ ), lise ve üni- 
versite ( $\left.\overline{\mathrm{X}}_{\text {lise=27.49, }}, \overline{\mathrm{X}}_{\text {üniv }}=29.19, \mathrm{I}-\mathrm{J}=-1.70\right)$ grupları arasında anlamlı fark görülmektedir. Deneyime açıklık kişilik boyutunda ise öğretmen ve üniversite öğrencileri ( $\overline{\mathrm{X}}_{\text {ŏgretmen }}=32.13, \overline{\mathrm{X}}_{\text {üniversite }}=32.13, \mathrm{I}-\mathrm{J}=1.69$ ) ile üniversite ve lise öğrencileri $\left(\overline{\mathrm{X}}_{\text {lise }}=31.40, \overline{\mathrm{X}}_{\text {univ }}=30.44, \mathrm{I}-\mathrm{J}=1.96\right)$ arasında anlamlı bir farklılık bulunmuştur.

Tablo 6 Kadın ve erkeklerde dışa dönüklük, uyumluluk, duygusal denge, sorumluluk ve deneyime açıklık kişilik boyutlarıla duygulara yaklaşma ve duygulardan kaçınma; benlik saygısı ve narsisizm toplam puan ortalamalarında ilişkin $t$ testi tablosu

\begin{tabular}{|c|c|c|c|c|c|c|c|}
\hline & & Gruplar & $\mathrm{N}$ & $\overline{\bar{X}}$ & Ss & $t$ & $\mathrm{p}$ \\
\hline \multirow{18}{*}{$\stackrel{\vec{\Xi}}{\stackrel{D}{\Xi}}$} & \multirow[t]{2}{*}{ Narsizm } & Kadın & 195 & 4.89 & 2.78 & -2.170 & .031 \\
\hline & & Erkek & 64 & 5.78 & 2.96 & -2.102 & .038 \\
\hline & \multirow[t]{2}{*}{ Benlik Saygısı } & Kadın & 195 & 31.80 & 5.09 & 1.318 & .189 \\
\hline & & Erkek & 64 & 30.82 & 5.28 & 1.294 & .199 \\
\hline & \multirow[t]{2}{*}{ Uyumluluk } & Kadın & 195 & 33.51 & 4.19 & .738 & .461 \\
\hline & & Erkek & 64 & 33.03 & 5.41 & .650 & .517 \\
\hline & \multirow[t]{2}{*}{ Dısadönüklük } & Kadın & 195 & 24.29 & 6.51 & 1.650 & .100 \\
\hline & & Erkek & 64 & 22.75 & 6.50 & 1.651 & .102 \\
\hline & \multirow[t]{2}{*}{ Sorumluluk } & Kadın & 195 & 29.48 & 6.67 & 1.178 & .240 \\
\hline & & Erkek & 64 & 28.32 & 7.14 & 1.138 & .258 \\
\hline & \multirow[t]{2}{*}{ Duygusal Denge } & Kadın & 195 & 22.46 & 5.65 & -1.744 & .082 \\
\hline & & Erkek & 64 & 23.92 & 6.27 & -1.653 & .101 \\
\hline & \multirow[t]{2}{*}{ Deneyime Açıklık } & Kadın & 195 & 30.16 & 4.60 & -1.653 & .099 \\
\hline & & Erkek & 64 & 31.28 & 4.93 & -1.597 & .113 \\
\hline & \multirow[t]{2}{*}{ Duygu Yaklaşma } & Kadın & 195 & 20.28 & 2.99 & 2.298 & .022 \\
\hline & & Erkek & 64 & 19.28 & 3.17 & 2.228 & .028 \\
\hline & \multirow[t]{2}{*}{ Duygu Kaçınma } & Kadın & 195 & 11.78 & 4.11 & -1.552 & .122 \\
\hline & & Erkek & 64 & 12.67 & 3.39 & -1.710 & .090 \\
\hline \multirow{15}{*}{ 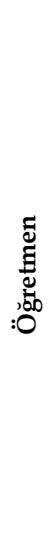 } & \multirow[t]{2}{*}{ Narsizm } & Kadın & 54 & 5.37 & 2.99 & .027 & .978 \\
\hline & & Erkek & 34 & 5.35 & 2.77 & .028 & .978 \\
\hline & \multirow[t]{2}{*}{ Benlik Saygısı } & Kadın & 54 & 32.92 & 4.49 & -.704 & .483 \\
\hline & & Erkek & 34 & 33.61 & 4.47 & -.705 & .483 \\
\hline & \multirow[t]{2}{*}{ Uyumluluk } & Kadın & 54 & 35.14 & 4.23 & .095 & .925 \\
\hline & & Erkek & 34 & 35.05 & 4.45 & .093 & .926 \\
\hline & \multirow[t]{2}{*}{ Dısadönüklük } & Kadın & 54 & 26.20 & 7.51 & .637 & .526 \\
\hline & & Erkek & 34 & 25.20 & 6.54 & .657 & .513 \\
\hline & \multirow[t]{2}{*}{ Sorumluluk } & Kadın & 54 & 31.14 & 7.54 & -.478 & .634 \\
\hline & & Erkek & 34 & 31.88 & 6.06 & -.502 & .617 \\
\hline & \multirow[t]{2}{*}{ Duygusal Denge } & Kadın & 54 & 23.46 & 6.06 & -1.289 & .201 \\
\hline & & Erkek & 34 & 25.20 & 6.35 & -1.275 & .207 \\
\hline & \multirow[t]{2}{*}{ Deneyime Açıklık } & Kadın & 54 & 31.79 & 5.64 & -.768 & .445 \\
\hline & & Erkek & 34 & 32.67 & 4.49 & -.808 & .421 \\
\hline & Duygu Yaklaşma & Kadın & 54 & 19.94 & 3.32 & -.258 & .797 \\
\hline
\end{tabular}


Öğretmenler ile Lise ve Üniversite Öğrencilerindeki Narsisizm Kişilik Özellikleri Benlik Saygısı ve Duygu Gereksinimi Arasındaki İlişkiler

\begin{tabular}{|c|c|c|c|c|c|c|c|}
\hline & & Erkek & 34 & 20.11 & 2.60 & -.273 & .786 \\
\hline & \multirow[t]{2}{*}{ Duygu Kaçınma } & Kadın & 54 & 11.62 & 4.24 & $\begin{array}{l}-.617 \\
\end{array}$ & .539 \\
\hline & & Erkek & 34 & 12.17 & 3.72 & -.635 & .527 \\
\hline \multirow{18}{*}{ 萬 } & \multirow{2}{*}{ Narsizm } & Kadın & 257 & 6.67 & 3.16 & $\begin{array}{l}-1.913 \\
\end{array}$ & .056 \\
\hline & & Erkek & 222 & 7.22 & 3.14 & -1.914 & .056 \\
\hline & \multirow[t]{2}{*}{ Benlik Saygısı } & Kadın & 257 & 30.35 & 5.76 & -.829 & .407 \\
\hline & & Erkek & 222 & 30.77 & 5.37 & -.834 & .405 \\
\hline & \multirow[t]{2}{*}{ Uyumluluk } & Kadın & 257 & 33.67 & 4.56 & .991 & .322 \\
\hline & & Erkek & 222 & 33.25 & 4.61 & .990 & .323 \\
\hline & \multirow[t]{2}{*}{ Dısadönüklük } & Kadın & 257 & 25.39 & 8.03 & $\begin{array}{l}.083 \\
\end{array}$ & .934 \\
\hline & & Erkek & 222 & 25.33 & 7.34 & .084 & .933 \\
\hline & \multirow[t]{2}{*}{ Sorumluluk } & Kadın & 257 & 27.64 & 7.11 & .501 & .617 \\
\hline & & Erkek & 222 & 27.31 & 7.12 & .501 & .617 \\
\hline & \multirow[t]{2}{*}{ Duygusal Denge } & Kadın & 257 & 22.62 & 6.13 & -3.588 & .000 \\
\hline & & Erkek & 222 & 24.55 & 5.53 & -3.615 & .000 \\
\hline & \multirow[t]{2}{*}{ Deneyime Açıklık } & Kadın & 257 & 30.91 & 5.03 & -2.226 & .026 \\
\hline & & Erkek & 222 & 31.95 & 5.18 & -2.222 & .027 \\
\hline & \multirow[t]{2}{*}{ Duygu Yaklaşma } & Kadın & 257 & 20.36 & 3.34 & 1.839 & .067 \\
\hline & & Erkek & 222 & 19.79 & 3.41 & 1.836 & .067 \\
\hline & \multirow[t]{2}{*}{ Duygu Kaçınma } & Kadın & 257 & 12.04 & 4.56 & -.815 & .415 \\
\hline & & Erkek & 222 & 12.37 & 4.27 & -.819 & .413 \\
\hline
\end{tabular}

Kadın ve erkeklerde dışa dönüklük, uyumluluk, duygusal denge, sorumluluk ve deneyime açıklık kişilik boyutlarıyla duygulara yaklaşma ve duygulardan kaçınma; benlik saygısı ve narsisizm toplam puan ortalamalarında anlamlı bir fark olup olmadığ $\mathrm{t}$ testi yapılarak belirlenmiştir. Buna göre üniversite grubunda, kadın ve erkeklerin narsisizm puan ortalamaları arasında anlamlı bir fark bulunmuştur ( $\mathrm{t}=-2.170, \mathrm{~F}=.925$, $\mathrm{p}<0.05)$. Erkeklerin narsisizm ortalama puanları kadınların puanlarından daha yüksektir $\left(\overline{\mathrm{X}}_{\text {erkek }}=5.78>\overline{\mathrm{X}}_{\text {kadnn }}=4.88\right)$. Üniversite grubunda kadın ve erkeklerin duygulara yaklaşma puan ortalamaları arasında yine anlamlı bir fark görülmektedir $(\mathrm{t}=2.298, \mathrm{~F}=.083, \mathrm{p}<0.05)$. Kadınların duygulara yaklaşma ortalama puanları erkeklerden daha yüksektir $\left(\overline{\mathrm{X}}_{\text {kadın }}=20.28>\overline{\mathrm{X}}_{\text {er- }}\right.$ kek=19.28). Lise grubunda duygusal denge kişilik boyutu cinsiyetler arasinda anlamlı bir farklılığa işaret ederken $(t=-3.588, F=3.154, p<0.05)$ erkeklerin duygusal denge puan ortalamalarının kadınlardan daha yüksek olduğu görülmektedir $\left(\overline{\mathrm{X}}_{\text {erkek }}=24.55>\overline{\mathrm{X}}_{\text {kadın }}=22.62\right.$ ). Lise grubunda ise deneyime açıklık kişilik boyutunda cinsiyetler arasında anlamlı fark bulunmuştur ( $\mathrm{t}=-2.226, \mathrm{~F}=.149, \mathrm{p}<0.05)$. Erkeklerin deneyime açıklık ortalama puanları kadınların puanlarından daha yüksektir $\left(\overline{\mathrm{X}}_{\text {erkek }}=31.95>\overline{\mathrm{X}}_{\text {ka- }}\right.$ $\mathrm{d} n=30.91)$. 


\section{Sonuç, Tartışma ve Öneriler}

Regresyon analizi sonuçları incelendiğinde üniversite grubunda benlik saygısının narsisizm kişilik özelliğini yordadığı görülmektedir. Bu grupta benlik saygısı, narsisizm toplam puan ortalamalarına ilişkin varyansın $\% 32$ 'sini açıklamaktadır $(\beta=.323, \mathrm{t}=4.458, \mathrm{p}<.05)$. Benlik saygısı lise grubunda da narsisizm kişilik özelliğini yordamıştır. Regresyon analizindeki $\beta$ değerleri incelendiğinde benlik saygisının bu grupta narsisizm toplam puan ortalamalarına ilişkin varyansın $\% 28$ 'ini açıkladığ görülmektedir $(\beta=.282, \mathrm{t}=6.133, \mathrm{p}<.05)$. Bu analizlerdeki benlik saygısının narsisizmi yordaması alanyazın ile paralellik göstermektedir. Benlik saygısının tamamen olumlu bir özellik olup olmadığı ya da benlik saygısı ölçeği ile ölçülen özelliğin olumlu bir özellik olup olmadığı son zamanlarda bazı araştırmacılar tarafından tartışılmaya başlanmıştır (Twenge ve Campbell, 2015, Baumeister Bushman, ve Campbell, 2000). Rosenberg'in (1965) benlik saygısı tanımı "bireyin kendisine karşı olumlu ve olumsuz tutumları" şeklindedir. Dolayısıyla Rosenberg'e göre, kişinin kendisine karşı olumlu ve olumsuz tüm tutumları, bireyin kendini ne kadar değerli hissettiğini etkilemekte, bu etki de benlik saygısına yansımaktadır. Birey kendini değerlendirirken olumlu bir tutum içindeyse benlik saygısı yüksek; olumsuz bir tutum içindeyse benlik saygısı düşük olmaktadır. Yüksek benlik saygısına sahip bireyler kendilerini toplumda değerli bir kişi görme eğilimindedirler ve kendilerine yönelik değerlendirmeleri tamamen olumlu yöndedir.

Yüksek benlik saygısı her ne kadar mutluluk, kendini iyi hissetme ve girişkenlik ya da gruplar içinde kendini daha iyi ifade etme ile ilişkilendirilse de (Baumeister, 2013) yakın tarihte yapılan bazı araştırmalar daha önce de değinildiği gibi benlik saygısının abartılı ve dengesiz biçimde artırılmasının narsisizme yol açabileceğini düşündürmektedir (Baumeister ve ark., 2003). Twenge ve Campbell (2015) özellikle 80'lerden bu yana hızlı bir şekilde yükselme eğilimi gösteren ve bu şekilde olumlu benlik algısıyla ilişkilendirilen normal narsisizmin patolojik narsisizmden daha tehlikeli olduğunu öne sürmektedir. Bu araştırmacılara göre benlik saygısı yüksek bireylerin başarıyı yakalamadaki istekleri, diğerlerinden üstün olduklarını kanıtlamaya yönelik tutumlarıyla ilişkilendirilmektedir (Wallace ve Baumeister 2002). Bu nedenle benlik saygisını artırmaya 
Öğretmenler ile Lise ve Üniversite Öğrencilerindeki Narsisizm Kişilik Özellikleri Benlik Saygısı ve Duygu Gereksinimi Arasındaki İlişkiler

dönük yaklaşımların pozitif yönde işlemediği hatta bireylerdeki narsisizm eğilimlerinin artmasına da neden olduğu vurgulanmaktadır (Twenge ve ark., 2008).

Lise öğrencileri değerlendirildiğinde gelişim dönemlerinden ergenlikte olmaları ve buna bağlı gelişen ergen benmerkezciliğin etkisiyle kendilerine aşırı güven duyup, kendi özelliklerini abartma eğilimleri; benlik saygısı ve narsisizm puanlarının yüksek olmasına neden olmuş olabilir. Ergen benmerkezciliğindeki aşırı kendine güven ve ergenin her şeyi yapabileceğini düşünmesi, kendisinin eşsiz ve biricik bir varlık olduğuna dair inanc1 (Steinberg, 2007) ergen birey tarafından yaşantı ürünü olmayan abartılı bir benlik saygısı olarak algılanmaya yol açmış olabilir. Rosenberg'in benlik saygısı ölçeğindeki "Kendimi en az diğer insanlar kadar değerli buluyorum.", "Bazı olumlu özelliklerim olduğunu düşünüyorum." ayrıca tersine çevrildiğinde "Kendimi genelde başarılı bir kişi olarak görme eğilimindeyim." şekline dönüşen maddeler; ergen benmerkezciliği ile yakın ilişkili görünmektedir. Narsist kişilik ölçeğinin ise "İyi olduğumu biliyorum çünkü herkes bana devamlı bunu söylüyor.", "İlgi odağı olmaktan hoşlanırım.”, "Önemli bir insan olacağım.”, "İmkân bulursam gösteriş yapma eğiliminde olurum." ve “Özel biri olduğumu düşünüyorum." gibi maddeleri büyük ölçüde ergen benmerkezciliği ile ilişkilidir. Üniversite öğrencileri beliren yetişkinlik döneminde bulunmaktadırlar. Bu dönem ergenliğe ait özelliklerin daha yoğun olduğu ve ergenlikteki kimlik araştırmasının daha derinlemesine yapıldığı bir dönemdir (Atak, 2011; Morsünbül, 2013). Üniversite grubunda da benlik saygısının narsisizmi yordaması bu açıdan ele alındığında lise grubu ile paraleldir. Öğretmen grubunda benlik saygısı narsisizmi yordamamaktadır. Bu durumu, bu grubun bir işe girmeyle beraber yetişkin dünyasının sorumluluklarına katılmaları ve Rosenberg'in (1965) de belirttiği gibi benlik saygısının oluşumunda bireyin yaşantıları sonucu kendi başarı ve başarısızlıklarının etkili olması ile açıklamak işlevsel gözükmektedir.

Regresyon analizi sonuçları incelendiğinde deneyime açıklık kişilik özelliği, üniversite grubunda narsisizm toplam puan ortalamalarına ilişkin varyansin $\% 28^{\prime}$ ini $(\beta=.277, \mathrm{t}=4.113, \mathrm{p}<.05)$; lise grubunda $\% 25$ 'ini $(\beta=$ $.250, \mathrm{t}=5.663, \mathrm{p}<.05)$; öğretmenlerde ise $\% 42$ 'sini $(\beta=.424, \mathrm{t}=3.448, \mathrm{p}<.05)$ açıklamaktadır. Tüm gruplarda deneyime açılık kişilik boyutunun nar- 
sisizmi yordadığ görülmektedir. Bu kişilik boyutu baskın bireyler; yaratıcılık, merak ve yeni düşüncelere açık olma gibi özellikler sergilerler (Morsünbül, 2014). Deneyime açıklık kişilik boyutu, diğer kişilik boyutlarından farklı olarak bilişsel özellikleri öne çıkan bir kişilik boyutudur. Deneyime açık bireyler; çok boyutlu düşünebilen, yeniliklere açı, yeni ve özgün fikirler üretebilen, hayal gücü gelişmiş, sanata karşı duyarl,, cesur, değişiklikten korkmayan ve meraklı bireyler olarak nitelendirilebilirler (Costa ve McCrae, 1992). Boyuttan düşük puan alan bireyler ise geleneksele bağlı kalma ve yeni bir şeylerdense alışılagelen bilineni seçme eğilimindedirler (Burger, 2016). Bu kişilik boyutunun narsisizmi yordaması bu boyutun cesur olma, değişiklik arama ve yeniliklere açık olma özellikleri ile ilişkilendirilebilir. Nitekim narsist kişiliğin yüksek öz güven algısı, bireyin kendisine verdiği abartılı değer ve çevredense kendisine odaklanma eğilimi (Akhtar, 1989) boyutun bu özellikleriyle örtüşmekte ve dinamiği açıklar nitelikte gözükmektedir. Buna ek olarak narsistik benlik; bireyin deneyimlerinden keyif almasını, başarılarıyla gurur duymasını, başarısızlık ve eksikliklerinden dolayı ise utanç ve öfke duygularının daha rahat üstesinden gelmesini sağlayabilmektedir (Rozenblatt, 2002). Bunlar deneyime açıklık tarafından destekleniyor olabilir. Ayrıca bu durum normal ve patolojik narsisizm ayrımı ile de yorumlanabilir. Normal narsisizm bireyi olumlu yönde motive ederek kendisi, çevresi ve çevrenin beklentileri doğrultusunda dış dünya ile başa çımada kısmen uyumlu hale getirmektedir (Rozenblatt, 2002). Bu araştırmada birbirinden farklı gruplar incelenmiş ve daha önceki alanyazın araştırmalarıyla paralel olarak deneyime açıklık ve narsisizm arasında kayda değer bir ilişki bulunmuştur.

Literatür tarandığında deneyime açıklığın yanı sıra dışa dönüklük kişilik boyutunun da narsisizmi yüksek düzeylerde yordadığı, uyumluluk ve duygusal denge boyutların ise narsisizm ile negatif korelasyonu görülmektedir (Bradlee ve Emmons, 1992; Paulhus, 2001; Paulhus ve Williams, 2002; Ames, Rose ve Anderson, 2006; Vernon, Villani, Vickers ve Harris, 2008; Uçar ve Konal, 2017). Lise öğrencileri grubunun regresyon sonuçları incelendiğinde, dışa dönüklük kişilik boyutunun narsisizm toplam puan ortalamalarına ilişkin varyansın \%27'sini açıkladığ görülmektedir $(\beta=.268, \mathrm{t}=5.836, \mathrm{p}<.05)$. Dişa dönüklük boyutu; sosyal beceri, girişkenlik ve konuşkanlık gibi özellikleri içermektedir (Morsün- 
bül, 2014). Genel olarak boyut, bir bireyin sosyal ilişkilerindeki rahatlık seviyesiyle ilişkilidir. Lise öğrencileri, ergen benmerkezciliğin etkisi ile dışa dönüklük kişilik özellikleri sergilediklerinde narsisizmin sürekli ilgi gösterilmeyi bekleme, göz önünde olma, övgü ve takdir toplama gibi özelliklerini ortaya koymakta ya da kendilerini öyle algılamaktadırlar. Dışa dönüklük boyutundaki sürekli diğer insanlar ile birlikte olma, insanlar ile zaman geçirip rahatlama ve eğlenme eğilimleri, narsist bireylerin diğer insanlar ile birlikte olma isteğiyle (Aslan, 2008) ilişkili görülmektedir. Ancak narsist birey; övgü almak, kendini göstermek için diğerleri ile birlikte olmaktadır. Narsisizm eğilimli bireylerin genel itibariyle yüksek benlik saygısına bağlı olarak dışa dönüklük kişilik özellikleri sergilediği düşünülmektedir (Twenge ve Campbell, 2015). Araştırmanın bu bulgusu alanyazındaki tartışmaları desteklemektedir. Üniversite grubunda ve öğretmen grubunda dışa dönüklük narsisizmi yordamamaktadır. Bu durum, bireylerin yaşla beraber deneyimlerin artması ve bunun sonucunda da birey tarafından dışa dönüklük özellikleriyle narsist kişilik özelliklerinin ayrımının yapılabilmesi şeklinde yorumlanabilir.

Duygusal denge kişilik boyutu lise $(\beta=-.112, t=-2.370, p<.05)$ ve üniversite $(\beta=-.150, \mathrm{t}=-2.301, \mathrm{p}<.05)$ gruplarında narsisizmi yordamış, öğretmen grubunda ise yordamamıştır. Ancak değerler negatif yöndedir. Buradan hareketle duygusal denge arttıkça narsisizmin azaldığı yorumu yapılabilir. Duygusal denge (nevrotik olmama) boyutu; eleştiriye açılık, sakinlik, rahatlık gibi özellikler üzerine kuruludur (Morsünbül, 2014). Dolayısıyla boyut, bireylerin kişilerle ve çevreyle uyumunun yanında duygusal kararlılık durumunu da yordar. Denge durumundaki bireylerden sakin, iyi uyum gösteren; aşırı ve uyumsuz duygusal tepkiler vermeyen bireyler olmaları beklenir (Burger, 2016). Bu özellikler narsisizm ile tamamen zit olan özelliklerdir. Bu nedenle lise ve üniversite grubunda negatif yönde ilişki çıkması ve öğretmen grubunda duygusal dengenin narsisizmi yordamaması beklenen bir durumdur. Lise grubunda uyumluluk narsisizmi negatif yönde yordamış $(\beta=-.102, \mathrm{t}=-2.207, \mathrm{p}<.05)$, öğretmen ve üniversite gruplarında yordamamıştır. Uyumluluk kişilik boyutu; saygıll, sempatik, anlayışlı ve samimi olma gibi özellikleri içerirken aynı zamanda bu özellikler uyumlu bireyleri kibar ve diğer insanlara karşı duyarlı da yapar (Berry ve ark., 2015). Narsisizm eğilimli birey- 
ler için tam tersine diğerlerini anlamaya çalışmak ve onların duygularının farkında olmak önem taşımamakta, diğerlerinin varlığı onun üstünlüğünü onaylamak ve çıkarlarını sağlamakla ilişkili görülmektedir. Biricik olduğuna inanan narsist birey; dışa dönüklük, iddialılık, kendinden son derece emin olma ve abartılı gösterişte bulunma gibi özellikleriyle de ön plana çıkmaktadır (Atay, 2010). Uyumluluğun lise grubunda narsisizmi negatif yönde yordaması, öğretmen ve üniversite grubunda ise yordamaması alanyazın ile uyumlu beklenen bir durumdur.

$\mathrm{Bu}$ araştırmada duygulara yaklaşma ve duygulardan kaçınma, araştırma yapılan üç grupta da narsisizmi yordamamıştır. Narsisizmin özellikle patolojik narsisizmin- özelliği olarak narsist bireylerin duygulardan yoksun hareket ederek duygulardan kaçınma ve olayları kendi çıkarları doğrultusunda değiştirme eğilimlinde oldukları, tüm güç ve kontrolün kendilerinde olmasını istedikleri; onlar için ne hissettiklerinden çok nasıl göründüklerinin önem taşıdığı bu bireylerin özellikleri olarak betimlenmektedir. Bu bakımdan duygulardan kaçınma ile narsisizm arasında ilişki olması beklenen bir durumdur. Alanyazın incelendiğinde duygulardan kaçınmanın nevrotiklikle yakın ilişkili olduğu görülmektedir (Maio ve Esses, 2001; Uçar, 2017). Duygulara yaklaşma ve duygulardan kaçınma puan ortalamaları tüm gruplarda düşük düzeydedir.

Yapılan araştırmalar narsisizm eğilimlerinin yaşa bağlı olarak değiştiğini, bir başka ifade ile farklı gelişim dönemlerinde narsisizm puanlarının yükselip azalma eğiliminde olduğunu ortaya koymaktadır. Bulgular özellikle ergen gruplarındaki narsisizm eğilimlerinin yetişkin gruplara göre daha fazla olduğunu göstermektedir (Carlson ve Gjerde, 2009). Bu araştırmada da lise grubunun -ergenlerin- narsisizm puan ortalamalarının ( $\overline{\mathrm{X}}=6.93)$ üniversite öğrencileri $(\overline{\mathrm{X}}=5.11)$ ve öğretmen grubundan $(\overline{\mathrm{X}}=5.36)$ yüksek olduğu bulgulanmıştır. Yapılan varyans analizi sonuçlarına göre narsisizm puan ortalamalarında anlamlı bir farklılık vardır ( $\mathrm{F}=33.764, \mathrm{p}<0.05)$. Bu bulgu alanyazındaki, narsisizmin özellikle 14-18 yaş aralığında belirgin şekilde arttı̆̆ı, 18-23 yaş aralığında ise hafif bir düşüş eğilimine girdiği bulgular ile paraleledir (Carlson ve Gjerde, 2009, Akıncı 2015; Özer ve ark., 2016). Bu araştırmanın bulgularında öğretmen grubunun narsisizm puan ortalamaları, üniversite öğrencilerinden yük- 
sek olarak saptanmıştır $\left(\overline{\mathrm{X}}_{\ddot{g} \text { ğretmen }}=5.36>\overline{\mathrm{X}}_{\text {üniv öğrenci= }}=11\right)$. Bu durum ulaşılabilen alanyazındaki bulgulardan farklı bir sonuçtur. Öğretmen grubunun narsisizm puan ortalamaları yüksek olmasına karşın yapılan tek yönlü varyans analizi sonucunda anlamlı bir farklılık çıkmamıştır. Bu bulgu alanyazında olduğu gibi lise grubunda narsisizm kişilik özelliğinin yüksek olması ancak daha sonra düşme eğilimine girmesi ile açıklanabilir.

Benlik saygısı ortalama puanlarında lise ve üniversite öğrencileri ile öğretmen grubu arasında anlamlı bir fark bulunmuştur. ( $\overline{\mathbf{X}}_{\text {ögret- }}$ men $=33.19>\overline{\mathrm{X}}_{\text {üniversite }}=31.56>\overline{\mathrm{X}}_{\text {lise }}=30.54$ ). Gruplar arasındaki bu farklılık yaşla beraber benlik saygısının artmasına işaret edebileceği gibi statünün yükselmesi ile benlik saygısının artmasına da işaret edebilir. Rosenberg (1965), bireylerin bazı etkinliklerde bulunduğunu ve bunun sonucu olarak da buradan başarı elde etmenin benlik saygısını artırdığını belirtmiştir.

Uyumluluk kişilik boyutu değerlendirildiğinde boyutun; saygılı, sempatik, anlayışlı ve samimi olma gibi özellikleri içerdiği (Morsünbül, 2014) ve bu boyuttan yüksek puan alan bireylerin; yardımsever, güvenilir ve şefkatli olma özellikleri görülmektedir (Burger, 2016), aynı zamanda bu özellikler onları kibar ve diğer insanlara karşı duyarlı da yapmaktadır (Berry ve ark., 2015). Uyumluluk özelliği düşük olan bireyler; işbirliğinden kaçma, inatçı ve kaba olma gibi özelliklere sahiptirler. Çevrelerine karşı kayıtsız, güvensiz ve şüpheci yaklaşan bu bireyler (McCrae ve Costa, 1987), aynı zamanda çıarları ve inançları için uzlaşmak yerine kavgayı seçme eğilimindedirler (Burger, 2016). Lise öğrencilerinin uyumluluk puan ortalamaları üniversite ve öğretmen grupları ile karşılaştırıldı ̆̆ında anlamlı bir farklılık göstermiştir $\left(\overline{\mathrm{X}}_{\text {ögretmen }}=35.11>\overline{\mathrm{X}}_{\text {lise }}=33.48>\overline{\mathrm{X}}_{\text {üni- }}\right.$ versite $=33.39$ ). Öğretmen grubunun uyumluluk puan ortalamalarının yüksek olması beklenen bir durumdur. Öncelikle uyumluluk kişilik özellikleri ile öğretmenlik mesleğinin gerektirdiği roller paraleldir. Öğretmenlerin uyumluluk puan ortalamaları ile üniversite ve lise öğrencileri arasındaki anlamlı farklılık, öğretmenlerin çalışması, iş yaşamının zaten uyumluluğu gerektirmesi ile açıklanabileceği gibi bulgu, öğretmenlerin özel okulda olmaları, iş kaybetme kaygıları ve bununla ilintili sosyal ortamın yarattığı baskı ile de açıklanabilir. Lise ve üniversite gruplarında ise 
uyumluluk puan ortalamaları arasında fark çıkmamıştır.

Dışa dönüklük boyutu; sosyal beceri, girişkenlik ve konuşkanlık gibi özellikleri içermektedir (Morsünbül, 2014). Genel olarak bir bireyin sosyal ilişkilerindeki rahatlık seviyesiyle ilişkili olan bir boyutudur. Bu boyuttan yüksek puan alan bireyler; sosyal, eğlenceyi seven, samimi, konuşkan, aktif ve çevresine hâkim olmayı seven tiplerdir (McCrae ve Costa, 1987). Uyarıcı sosyal çevre aramaya eğilimli olan bu bireylerin sempatik olmaları da önemli özellikleri arasında sayılmaktadır (Berry ve ark., 2015). Dışa dönüklük kişilik boyutunda lise ve üniversite öğrencileri arasında anlamlı bir fark çıkarken $\left(\overline{\mathrm{X}}_{\text {ögretmen }}=25.81>\overline{\mathrm{X}}_{\text {lise }}=25.36>\overline{\mathrm{X}}_{\text {üniversite }}\right.$ =23.39) her üç grup için anlamlı bir fark söz konusu değildir. Bu duru$\mathrm{mu}$, lise öğrencilerinin ergenliğin psikososyal gelişim özellikleri olan akran gruplarına ait olma isteği ve ergen benmerkezciliği ile açıklamak işlevseldir. Nitekim ergen benmerkezciliğine bağlı uyarıcı arama ihtiyacının sonucunda uyarıcı sosyal çevre arayışı betimlenen bir durumdur (Steinberg, 2007).

Sorumluluk kişilik boyutu; disiplinli olma, kendini kontrol etme, düzen ve başarma ile ilişkili özellikleri içermektedir (Morsünbül, 2014). Boyuttan yüksek puan alan bireylerin hazzı erteleyebilen, sorumluluk sahibi, disiplinli davranan, verimli ve üretken olmayı hedefleyen kişiler olduğu söylenebilir (McCrae ve John, 1992). Bunların yanı sira sorumlu bireylerin başarma duygusu yüksektir; bireyler etik, ilke ve değerlere belirgin şekilde bağlllık gösterme eğilimindedir (Neuman ve Wright, 1999). Sorumluluk kişilik boyutunda öğretmen grubu ile lise ve üniversite öğrencileri grupları arasında anlamlı bir fark çıkmıştır ( $\overline{\mathrm{X}}_{\text {ögret- }}$ $\mathrm{men}=31.43>\overline{\mathrm{X}}_{\text {üniversite }}=29.19>\overline{\mathrm{X}}_{\text {lise }}=27.49$ ). Öğretmen grubunun sorumluluk kişilik boyutundan yüksek puan alması beklenen bir durumdur. Daha önce de belirtildiği gibi araştırma grubundaki öğretmenler özel bir lisede çalışmaktadırlar. Bulgular, iş koşulları nedeni ile bireylerin bu kişilik özelliklerini öne çıkarması ve öyle davranmak zorunda kalması ile yorumlanabilir. Üniversite ve lise öğrencileri arasında da anlamlı farklılık çıkmıştır. Lise öğrencilerinin ergenlik dönemi özelliği olan ergen benmerkezciliğin etkisinde olmaları ile bu bulgu açıklanabilir. Ergen benmerkezciliğinin özelliği olan kişisel efsane boyutuna göre birey her şeyi yapabileceğine inanmakta; kendi yetenek ve kapasitesi ile duygularını 
da aşırı abartmaktadır. Biyolojik yaklaşım açısından bakıldığında ergenlerin prefrontal kortexleri ergenlik boyunca gelişimini devam ettirdiği için ergenler mantıklı ve planlı olmaktan çok duygusal olarak davranmaktadırlar. Prefrontal kortex, duyguların kontrollünü sağlayan, planlama ve karmaşık işlemleri sınıflama gibi üst düzey bilişsel işlevleri gerçekleştiren beyin bölgesidir (Steinberg, 2007 Carlson, 2011).

Duygusal denge kişilik boyutunda yapılan tek yönlü varyans analizi sonucuna göre gruplar arasında fark çıkmamıştır $\left(\overline{\mathrm{X}}_{\ddot{o g ̆ r e t m e n}}=24.13>\overline{\mathrm{X}}_{\text {üniversi- }}\right.$ te $=22.82>\overline{\mathrm{X}}_{\text {lise }}=23.51$ ). Duygusal denge alt ölçeğinden alınabilecek en üst puanın 42 olduğu dikkate alındığında genel olarak duygusal denge puanları düşüktür. Bu durum nevrotiklik kişilik boyutunun yüksekliğine işaret etmektedir. Nevrotik bireyler, duygusal olarak kararsız yani duyguları sıkça değişme eğiliminde olan, duygusal sıkıntılar yaşayan, endişeli, sinirli ve özgüveni düşük bireylerdir (McCrae ve Costa, 1987). Duygusal dengesizlik, kaygıya ve gerginliğe neden olmakta aynı zamanda düşmanca davranışlara eğilimli olmayı da artırmaktadır (Berry ve ak.,2015).

Deneyime açıklık kişilik boyutunda öğretmen grubu ile lise ve üniversite öğrencileri grupları arasında fark çıkarken lise ve üniversite gruplarının kendi arasında da anlamlı fark çıkmıştır $\left(\overline{\mathrm{X}}_{\text {ŏgretmen }}=32.13>\overline{\mathrm{X}}\right.$ lise $=31.40>\overline{\mathrm{X}}_{\text {üniversite}}=30.44$ ). Deneyime açıklık kişilik boyutu, merak ve yeni düşüncelere açık olma gibi en fazla bilişsel özellikler taşıyan kişilik boyutudur (Morsünbül, 2014). Boyuttan yüksek puan alanlar; çok yönlü düşünebilen, yeniliklere açık, özgün fikirler üretebilen, hayal gücü kuvvetli, sanata karşı duyarlı, cesur, değişiklikten korkmayan ve meraklı bireyler olarak nitelendirilebilirler (Costa ve McCrae, 1992). Boyuttan düşük puan alan bireylerde ise geleneksele bağlllık ve bununla ilgili olarak yeni bir şeylerdense alışılageleni seçme eğilimi vardır (Burger, 2016). Boyut, genç ve ileri yaşta olan bireyler için farklı sonuçlar vermiş, araştırmalar gençlerin ileri yaş grubuna göre boyuttan önemli bir şekilde yüksek puan aldıklarını ortaya koymuştur (Costa ve ark., 1986). Bu araştırmanın bulgularında öğretmen grubunun deneyime açıklık ortalama puanları en yüksek olan grup olduğu ve öğretmen grubunun lise ve üniversiteden anlamlı bir şekilde farklılaştığı görülmektedir. Lise grubu ve üniversite öğrencileri arasında da anlamlı bir farklılık ortaya çıkmıştır. 
Lise grubunun ortalama puanları daha yüksektir. Lise öğrencilerinin deneyimlere açık olması beklenen bir durumdur. Ergenlikte olmaları yeni olguları araştırmaya ve kimlik geliştirme süreci içinde olmaları nedeni ile alanyazınla uyumludur (Costa ve ark., 1986, Steinberg, 2007). Öğretmen grubunun ortalamasının yüksek olması da bu şekilde değerlendirilebilir. Öğretmen grubundaki katılımcıların yaş ortalamalarına bakıldığında yaşlarının 22 ile 41 arasında değiştiği, tepe değerin -en çok

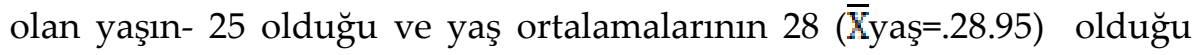
görülmektedir. Bu durum, bu grubun büyük bir çoğunluğunun genç yetişkinlikte olduğunu gösterir ve bununla ilintili olarak alanyazın ile paralel bir şekilde deneyime açıklık kişilik boyutunun yüksek olduğu söylenebilir. Ayrıca genç yetişkinlik döneminde karşılaşılan bir olgu olan beliren yetişkinlik,18-28 yaşlar arasındadır. Bu dönemde ergenliğin temel özelliklerinin yani kimlik arayışı, yeni yaşantılar deneme ve risk alma gibi davranışların daha yoğun ve şiddeti bir biçimde yaşandığ 1 öngörülmektedir. Türkiye' de yapılan araştırmalarda da 18-28 yaşlar arasındaki bireylerin beliren yetişkinliğin bu özelliklerini taşıdığı bulgulanmıştır (Atak, 2011; Morsünbül, 2013). Dolayısıyla bu bulgu da literatürle uyumludur. Bu araştırmanın ilginç olan sonucu, üniversite öğrencilerinin öğretmen ve lise grubundan daha düşük deneyime açılık puan ortalamasına sahip olmasıdır. Üniversite öğrencileri de genç yetişkinlik döneminde oldukları için bu boyuttan yüksek puan almaları alanyazından hareketle beklenmektedir. Üniversite öğrencilerinin deneyime açılık boyutundan düşük puan almaları; yeni bir çevrede olmaları ve bir formasyon eğitimi almaları nedeni ile bocalayıp kendilerini deneyimlere kapatmalarından kaynaklanıyor olabilir.

Duygulara yaklaşma $\left(\overline{\mathrm{X}}_{\text {lise }}=20.09>\overline{\mathrm{X}}_{\text {üniversite }}=20.03>\overline{\mathrm{X}}_{\text {oğretmen }}=20.01\right)$ ve duygulardan kaçınma ( $\left.\overline{\mathrm{X}}_{\text {lise }}=12.19>\overline{\mathrm{X}}_{\text {üniversite }}=12.00>\overline{\mathrm{X}}_{\text {oğretmen }}=11.84\right)$ özellikleri arasında gruplar arasında fark çıkmamıştır. Ölçeklerden alınacak en fazla puanın 50 olduğu dikkate alındığında tüm grupların ortalamaları oldukça düşüktür. Maio ve Esses'e (2001) göre insanlar bir duygu deneyimi yaşadıklarında kendilerinin ve diğerlerinin duygularını anlamak için gereksinim duyarlar; bu gereksinim, duygulara yaklaşmak ve duygulardan kaçınmak şeklinde ortaya çıkan güdülenmeye yol açar. Bireylerden beklenen, rahatsız edici duygulardan kaçınma güdüsüyken; duy- 
gulara yaklaşma güdüsünde ise olumlu duygu yaşantıları ön plana çıkmaktadır (Lang, 1995; Maio ve Esses, 2001). Bu bulgudan hareketle, gruplar arasında kendi duyguları ve diğerlerin duygularını anlama gereksiniminde bir fark olmadığ 1 gibi araştırma grubundakilerin duygu gereksinimlerinin düşük olduğu sonucuna varılabilir.

Yapılan $t$ testi sonucuna göre üniversite grubunda kadın ve erkeklerin narsisizm puan ortalamaları arasında anlamlı bir fark bulunmuştur ( $\mathrm{t}=-$ 2.170, F=.925, $\mathrm{P}<0.05)$. Erkeklerin narsisizm ortalama puanları kadınlardan daha yüksektir $\left(\overline{\mathrm{X}}_{\text {erkek }}=5.78>\overline{\mathrm{X}}_{\text {kadnn }}=4.88\right)$. Bu bulgu alan yazını ile paraleldir. Erkeklerin narsisizm puan ortalamaları kadınlardan daha fazladır (Akhtar ve Thomson, 1982; Philipson, 1985). Ancak bu araştırmada yalnız üniversite grubunda kadın ve erkekler arasında anlamlı fark çıkmıştır. Bu bulgu, Twenge ve Campbell'ın (2015) narsisizmin kadınlarda da yükseliş eğiliminde olduğu görüşü ile paraleldir çünkü diğer gruplar arasında fark çıkmamıştır.

Yapılan araştırma doğrultusunda Coopersmith' in benlik saygısı ölçeğinden elde edilen sonuçlar ile araştırmanın tekrarlanması ve ergen benmerkezciliği ile narsisizm ve benlik saygısı arasındaki ilişkilerin tartışılması önerilmektedir. 
EXTENDED ABSTRACT

\title{
Relationships Between Narcissism Personality Trait Need for Affect and Self Esteem At Teacher Univer- sity and High School Student
}

\author{
Mehmet Ertuğrul Uçar - Bilge Konal \\ Aksaray University - Özel Niğde Final Temel Lisesi
}

Narcissism is a personality trait characterized by a sense of superiority and a desire for respect and admiration from others. A common belief, both in psychology and in popular culture, is that narcissism represents a form of excessive self-esteem. Some psychologists suggest that narcissism related an exaggerated form of high self-esteem or inflated selfesteem. So that self-esteem increase narcissist personality trait. Selfesteem indicates whether people have a low or high sense of their overall self-worth.

Personality is one of the important domains of psychology and it deals with organized traits which are emotional, cognitive, and social. Various approaches have been proposed to examine personality but the Big-Five Personality Theory which suggests personality traits can be assessed under the five-factor has begun to come to the fore. These factors are extraversion, agreeableness, emotional stability, conscientiousness and openness to experience. Self esteem indicates whether people have a low or high sense of their overall self-worth. The need for affect is defined as general motivation level of people for participate in or flee form situations and activities contain affect. According to Maio and Esses the need for affect reflects a stable intrinsic motivation that can be measured with the help of self-report items. They developed need for affect scale that consist two sub dimensions, emotion approach and emotion avoidance. People high in the need for affect become more deeply involved in emotion-inducing events such as the screening of a drama, reading novel, poet or a action film. People low in the need for affect 
become avoid in emotion inducing events. Emotion approach and emotion avoidance related personal traits as well. Both personality traits and self esteem effect on Narcissism. Some studies assert that narcissistic personality tendencies are change with age or increase and decrease different development stage. In light of the literature the aim of this study is to examine whether extraversion, agreeableness, emotional stability, conscientiousness and openness to experience emotion approach, emotion avoidance and self esteem's predicts narcissism or not at high school teachers, high school and university students.

Method: Research group consisted of 826 (61.3\% female, 38.7\% male) teachers $(\mathrm{n}=88,10.7 \%)$, high school( $\mathrm{n}=479,58.2 \%)$ and university students(n=259, 31.1\%). To collect data Personal data form was used to obtain data on demographical features of the participants such as age and gender. Quick Big Five Personality Test, self esteem Scale and narcissism scale. To analyze the data Pearson Correlation and a regression model in order to investigate extraversion, agreeableness, emotional stability, conscientiousness and openness to experience emotion approach, emotion avoidance and self esteem's predict narcissism. To used ANOVAs for is there any differences between teacher, high school and university student. To used $t$ test in order to investigate how differences extraversion, agreeableness, emotional stability, conscientiousness and openness to experience emotion approach, emotion avoidance and self esteem narcissism between female and men.

The preliminary analyses showed that extraversion, agreeableness, emotional stability, conscientiousness and openness to experience and self-esteem's predict narcissism at high school teachers, high school and university students. Firstly regression analyzed showed that openness to experience, agreeableness, emotional stability and self-esteem significantly predicts narcissism. Self esteem explained of $32 \%$ variance totally in narcissism at university students $(\beta=.323, \mathrm{t}=4.458, \mathrm{p}<0.05)$. Openness to experience explained of $28 \%$ variance totally in narcissism $(\beta=.277$, $\mathrm{t}=4.113, \mathrm{p}<.05)$. Emotional stability explained of $28 \%$ variance totally in narcissism at university students $(\beta=-.150, \mathrm{t}=-2.301, \mathrm{p}<0.05)$ but direction is negativity its means when emotional stability decrease narcissism is increased. To be studied carefully values of $\beta$ only openness to experi- 
ence significantly predict narcissism at teachers. Openness to experience explained of $42 \%$ variance totally in narcissism $(\beta=.424, \mathrm{t}=3.448, \mathrm{p}<0.05)$. Self esteem explained of $28 \%$ variance totally in narcissism at high school students $(\beta=.282, \mathrm{t}=6.133, \mathrm{p}<.05)$. Extraversion explained of $27 \%$ variance totally in narcissism at high school students $(\beta=.268, t=5.836$, $\mathrm{p}<.05)$. Openness to experience explained of $27 \%$ variance totally in narcissism $(\beta=.250, \mathrm{t}=5.663, \mathrm{p}<.05)$ at high school students. Emotional stability explained of $11 \%$ variance totally in narcissism $(\beta=-.112, t=-2.370$, $\mathrm{p}<.05)$ but direction is negativity its means when emotional stability decrease narcissism is increased. Second one way ANOVAs analyses show that there are significantly differences between high school student and university student and teacher groups in narcissism score $(\mathrm{F}=33.764$, $\mathrm{p}<0.05)$. To used Scheffe test to analyzed groups differences. Scheffe test show that there is significantly difference between high school student and university students $\left(\overline{\mathrm{X}}_{\text {highschool}}=6.93, \overline{\mathrm{X}}_{\text {university }}=5.11, \mathrm{I}-\mathrm{J}=-1.81\right)$ in narcissism and there is significantly difference between high school and teacher $\left(\overline{\mathrm{X}}_{\text {highschool }}=6.93, \overline{\mathrm{X}}_{\text {teacher }}=5.36, \mathrm{I}-\mathrm{J}=1.56\right)$. T test show that there is significantly difference between $t$ test shows that there is significantly difference between male and female in narcissism score at university student. Male's narcissism scores are higher than females in university student.

\section{Kaynakça / References}

Akhtar, S. (1989). Narcissistic personality disorder: Descriptive features and differential diagnosis. Psychiatric Clinics of North America. 12(3), 505-29.

Akhtar, S. ve Thomson, J. A. (1982). Overview: Narcissistic personality disorder. The American journal of psychiatry 139(1),12-20.

Akıncl, İ. (2015). The relationship between the types of narcissism and psychological well-being: The roles of emotions and difficulties in emotion regulation. Middle East Technical University, The Department of Psychology, (Master's Thesis), Ankara. 
Ames, D. R., Rose, P., ve Anderson, C. P. (2006). The NPI-16 as a short measure of narcissism. Journal of Research in Personality, 40(4), 440-450.

Anlı, İ., ve Bahadır, G. (2007). Kendilik psikolojisine göre narsisistik ve sinır kişilik bozukluğu. Psikoloji Çalı̧̧maları Dergisi, 27, 1-12.

Apple, Gnambs ve Maio (2012). A short measure of the need for affect. Journal of Personality Assessment 1(1), 1- 9.

Arnett, J. J. (1998). Learning to stand alone: The contemporary American transition to adulthood in cultural and historical context. Human development, 41(5-6), 295-315.

Arnett, R. C. (1997). Communication and community in an age of diversity. Communication ethics in an age of diversity, (edit:Josina M. Makau and Ronald C. Arnett)27-47. Universitiy of Illinois press: Chicago

Aslan, S. (2008). Kişilik, huy ve psikopatoloji. Rewiews, Cases and Hypotheses in Psychiatry RCHP, 2(1-2), 7-18.

Atak, H. (2011). Kimlik gelişimi ve kimlik biçimlenmesi: Kuramsal bir değerlendirme. Psikiyatride Güncel Yaklaşımlar, 3(1),163-213.

Atay, S.(2009). Narsistik kişilik envanteri'nin Türkçe'ye standardizasyonu. İktisadi ve İdari Bilimler Fakültesi Dergisi, 11(1), 1-16.

Atay, S. (2010). Çalışan Narsist, 1. Baskı. Namar Yayınları: İstanbul.

Baumeister, R. F. (Ed.). (2013). Self-esteem: The puzzle of low self-regard. Springer Science ve Business Media.

Baumeister, R. F., ve Tice, D. M. (1986). Four selves, two motives, and a substitute process self-regulation model. Public self and private self, 63-74. Springer: New York

Baumeister, R. F., Bushman, B. J., ve Campbell, W. K. (2000). Self-esteem, narcissism, and aggression: Does violence result from low selfesteem or from threatened egotism?. Current Directions in Psychological Science, 9(1), 26-29.

Baumeister, R. F., Campbell, J. D., Krueger, J. I., ve Vohs, K. D. (2003). Does high self-esteem cause better performance, interpersonal success, happiness, or healthier lifestyles? Psychological Science in The Public Interest, 4(1), 1-44. 
Baumeister, R. F., Tice, D. M., ve Hutton, D. G. (1989). Self-presentational motivations and personality differences in self-esteem. Journal of Personality, 57(3), 547-579.

Berry, J. W., Poortinga, Y. H., Breugelmans, S. M., Chasiotis, A., ve Sam, D. L. (2015). Kültürlerarası psikoloji: Araştırma ve uygulamalar.(çev. ed.: Leman Pınar Tosun). Ankara: Nobel.

Blankstein, K. R., Flett, G. L., Koledin, S., ve Bortolotto, R. (1989). Affect intensity and dimensions of affiliation motivation. Personality and Individual Differences, 10(11), 1202-1203

Bradlee, P. M., ve Emmons, R. A. (1992). Locating narcissism within the interpersonal circumplex and the five-factor model. Personality and Individual Differences, 13(7), 821-830.

Burger, J.M. (2016). Kişilik (5.Baskı). İnan Deniz Erguvan Sarığlu (Çev.). İstanbul: Kaknüs.

Büyükoztürk, S., Kılıç Çakmak, E., Akgün, O. E., Karadeniz, S., ve Demirel, F. (2008). Bilimsel araştırma yöntemleri. Ankara: Pegem Akademi.

Campbell, W. K., ve Foster, J. D. (2007). The narcissistic self: Background, an extended agency model, and ongoing controversies. The self, 115-138.Psylogy press: New York.

Carlson, K. S., ve Gjerde, P. F. (2009). Preschool personality antecedents of narcissism in adolescence and young adulthood: A 20-year longitudinal study. Journal of Research in Personality, 43(4), 570578.

Carlson, N. R. (2011). Fizyolojik psikoloji davranışın nörolojik temelleri. Nobel Akademik Yayıncılık.

Costa Jr, P. T., ve McCrae, R. R. (1995). Domains and facets: Hierarchical personality assessment using the Revised NEO Personality Inventory. Journal of Personality Assessment, 64(1), 21-50.

Costa Jr, P. T., McCrae, R. R., Zonderman, A. B., Barbano, H. E., Lebowitz, B., ve Larson, D. M. (1986). Cross-sectional studies of personality in a national sample: II. Stability in neuroticism, extraversion, and openness. Psychology and Aging, 1(2), 144.

Costa, P.T. ve McCrae, R.R. (1992). NEO-PIR, Professional Manual. Psychological Assessment Resources, Inc. Florida. 
Öğretmenler ile Lise ve Üniversite Öğrencilerindeki Narsisizm Kişilik Özellikleri Benlik Saygısı ve Duygu Gereksinimi Arasındaki İlişkiler

Çuhadaroğlu, F. (1986). Adolesanlarda benlik saygisı. Uzmanlık Tezi, Hacettepe Üniversitesi Tıp Fakültesi Psikiyatri Anabilim Dall, Ankara.

Digman, J. M. (1990). Personality structure: Emergence of the five-factor model. Annual Review of Psychology, 41(1), 417-440.

Doğan, S., Uğurlu, M., ve Canat, S. (2007). Narsisistik kişilik bozukluğu. Turkiye Klinikleri. Journal of Internal Medical Sciences, 3(12), 53-60.

Dollard, J., Miller, N. E., Doob, L. W., Mowrer, O. H., ve Sears, R. R. (1939). Frustration and aggression.yale University press: New Heven

Duyan, V., Uçar, M. E., ve Kalafat, T. (2011). Duygu Gereksinimi Ölçeği'nin Türk Kültürüne Uyarlanması ve Psikometrik Niteliklerinin Belirlenmesi. Eğitim ve Bilim, 36(161).

Emmons, R. A. (1987), "Narcissism: Theory and Measurement", Journal of Personality and Social Psychology, Vol. 52, No. 1, pp.11-17

Epstein, S. (1998). Cognitive-experiential self-theory. In Advanced personality (pp. 211-238). Springer, Boston, MA.

Foster, J. D., ve Campbell, W. K. (2007). Are there such things as "narcissists" in social psychology? A taxometric analysis of the Narcissistic Personality Inventory. Personality and Individual Differences, 43(6), 1321-1332.

Fraenkel, J. R., Wallen, N. E., ve Hyun, H. H. (1993). How to design and evaluate research in education (Vol. 7). New York: McGraw-Hill.

Freud, S. (1914). Narsizm Üzerine ve Schreber vakası (5. bs., çev. B. Büyükal ve S.M. Tura). İstanbul: Metis Yayınları (Orijinal makalenin yayın tarihi).

Fujita, F., Diener, E., ve Sandvik, E. (1991). Gender differences in negative affect and well-being: the case for emotional intensity. Journal of Personality and Social Psychology, 61(3), 427.

Geçtan, E. (2015). Psikodinamik Psikiyatri ve Normaldışı Davranışlar. İstanbul: Metis Yayınları.

Goldberg, L. R. (1992). The development of markers for the Big-Five factor structure. Psychological Assessment, 4(1), 26.

Grijalva, E., Newman, D. A., Tay, L., Donnellan, M. B., Harms, P. D., Robins, R. W., ve Yan, T. (2015). Gender differences in narcissism: A meta-analytic review. Psychological Bulletin, 141(2), 261. 
Güngör, İ. H., Arıcak, O. T., ve Ekşi, H. (2012). Value preferences predicting narcissistic personality traits in young adults. Educational Sciences: Theory and Practice. 12.2, 1281-1290.

Güngör, N. D., ve Selçuk, F. Ü. (2015). Narsisistik kişilik envanteri (nke16) Türkçe uyarlaması.

https://www.researchgate.net/profile/Fatma Selcuk/publication/273120I Izard, C. E. (2007). Basic emotions, natural kinds, emotion schemas, and a new paradigm. Perspectives on Psychological Science, 2(3), 260280.

Karasar, N. (2004). Bilimsel arastirma yöntemleri. Ankara: Nobel Yayıncilik.

Kernberg, O. (1975). Sınır Durumlar ve Patolojik Narsisizm. (Çev. M. Atakay), Birinci Bask1, Metis Kitabevi.

Kızıltan, H. (2000). Narcissistic Personality Inventory (NPI) Ölçeğinin Türkçe Formu Dil Eşdeğerliliği, Güvenilirlik ve Geçerlilik Çalışmaları. Yayınlanmamış Yüksek Lisans Tezi, IÜ̈SBE, İstanbul.

Kohut, H. (1971). Kendiliğin Çözümlenmesi. Çev. Cem Atbaşoğlu, Banu Büyükkal, Cüneyt İşcan. İstanbul: Metis Yayınları.

Kring, A. M., ve Gordon, A. H. (1998). Sex differences in emotion: expression, experience, and physiology. Journal of Personality and Social Psychology, 74(3), 686.

Lang, P. J. (1995). The emotion probe: Studies of motivation and attention. American Psychologist, 50(5), 372.

Lasch, C. (2006). Narsisizm kültürü. Çev. Suzan Öztürk ve Ümit Hüsrev Yolsal, Ankara: Bilim ve Sanat Yayınları.

Lazarus, R. S. (1991). Cognition and motivation in emotion. American Psychologist, 46(4), 352-367.

Leventhal, H., ve Scherer, K. (1987). The relationship of emotion to cognition: A functional approach to a semantic controversy. Cognition and Emotion, 1(1), 3-28.

Lowen, A. (2016). Narsisizm: Gerçek Benliğin İnkarı. Cem Yayınevi.

Maio, G. R., ve Esses, V. M. (2001). The need for affect: Individual differences in the motivation to approach or avoid emotions. Journal of Personality, 69(4), 583-614.

McCrae RR, Costa PT. (2003). Personality in adulthood. New York: The Guilford Press; 48-63 
McCrae, R. R. (2009). Personality profiles of cultures: Patterns of ethos. European Journal of Personality, 23(3), 205-227.

McCrae, R. R., ve Costa Jr, P. T. (1999). A five-factor theory of personality. Handbook of personality: Theory and Research, 2, 139-153.

McCrae, R. R., ve Costa, P. T. (1987). Validation of the five-factor model of personality across instruments and observers. Journal of Personality and Social Psychology, 52(1), 81.

McCrae, R. R., ve John, O. P. (1992). An introduction to the five-factor model and its applications. Journal of Personality, 60(2), 175-215.

McShane, S.L., Von Glinow, M.A. (2005), Organizational Behavior: Emerging Realites For The Workplace Revolution, McGraw Hill Companies, Inc., New York.

Morsünbül, Ü. (2013). Beliren yetişkinler mi, beliren üniversiteli yetişkinler mi? Risk alma ve kimlik biçimlenmesi üzerinden bir inceleme. İlköğretim Online, 12(3), 873-885.

Morsünbül, Ü. (2014). Hızlı büyük beşli kişilik testi türkçe versiyonu geçerlilik ve güvenirlik çalışması. Düşünen Adam: Psikiyatri ve Nörolojik Bilimler Dergisi, 27(4), 316-322.

Neuman, G. A. ve Wright, J. (1999). Team effectiveness: Beyond skills and cognitive ability, Journal of Applied Psychology, 84 (3), 376389.

Nolen-Hoeksema, S., ve Girgus, J. S. (1994). The emergence of gender differences in depression during adolescence. Psychological Bulletin, 115(3), 424-443.

Özakkaş, T. (2006). (Ed.), Narsistik ve Borderline Kișilik Bozuklukları, Litera Yayıncılık. Istanbul.

Ozan, E., Kırkpınar, İ., Aydın, N., Fidan, T., ve Oral, M. (2008). Narsisistik kişilik bozukluğu: Gelişim süreçleri ve yaşamı. RCHP, Psikiyatride Derlemeler, Olgular ve Varsayımlar Dergisi, 2(1-2), 25-38

Özer, Ö., Uğurluoğlu, Ö., Kahraman, G., ve Avcl, K. (2016). Hemşirelerin karanlık kişilik özelliklerinin sosyo-demografik değişkenler açısından incelenmesi. Celal Bayar Üniversitesi Sosyal Bilimler Dergisi, 14(3), 205-218.

Paulhan, F. (2013). The laws of feeling. Routledge: British Libriary.

Paulhus, D. L. (2001). Normal narcissism: Two minimalist accounts. Psychological Inquiry, 12(4), 228-230. 
Paulhus, D. L., ve Williams, K. M. (2002). The dark triad of personality: Narcissism, Machiavellianism, and psychopathy. Journal of Research in Personality, 36(6), 556-563.

Philipson, I. (1985). Gender and narcissism. Psychology of Women Quarter$l y, 9(2), 213-228$.

Pincus, A. L., ve Lukowitsky, M. R. (2010). Pathological narcissism and narcissistic personality disorder. Annual Review of Clinical Psychology, 6, 421-446.

Raskin, R. N., ve Hall, C. S. (1979). A narcissistic personality inventory. Psychological reports.

Raskin, R., ve Terry, H. (1988). A principal-components analysis of the Narcissistic Personality Inventory and further evidence of its construct validity. Journal of Personality and Social Psychology, 54(5), 890-902.

Robert, B. W., Edmonds, G., ve Grijalva, E. (2010). It is Developmental Me Not Generation Me: Developmental Changes are More Important than Generational Changes in Narcissism. Perspectives in Psychological Science, 5(1), 97-102.

Rose, P. (2002). The happy and unhappy faces of narcissism. Personality and Individual Differences, 33(3), 379-391.

Rosenberg, M. (1965). Rosenberg self-esteem scale (RSE). Acceptance and commitment therapy. Measures package, 61, 52.

Rozenblatt, S. (2002), In Defence of Self: The Relationship of Self-Esteem and Narcissism to Agressive Behavior Long Island University, Psychology, Yayınlanmamış Doktora Tezi, USA

Santrock, J. W. (2012). Ergenlik. Nobel Akademik Yayıncılık.

Schwarz, N. (1990). Feelings as information: Informational and motivational functions of affective states. Guilford Press: New York

Steinberg, L. (2007). Ergenlik (çev. ed. F. Çok). Ankara: İmge Yay.

Taymur, İ., ve Türkçapar, M. H. (2012). Kişilik: tanımı, sınıflaması ve değerlendirmesi. Psikiyatride Güncel Yaklaşımlar, 4(2), 154-177.

Tolman, E. C. (1923). A behavioristic account of the emotions. Psychological Review, 30(3), 217-227.

Twenge, J. M., Konrath, S., Foster, J. D., Campbell, W. K., ve Bushman, B. J. (2008). Further evidence of an increase in narcissism among college students. Journal of Personality, 76(4), 919-928. 
Twenge, J., ve Campbell, W. (2015). Asrm vebası: Narsizim illeti. (Çev. KORKMAZ, Ö), İstanbul: Kaknüs Yayınları.

Uçar, M. E. (2017). Duygu gereksinimi ölçeği'nin kısa formunun Türkçeye uyarlama çalışması. Mehmet Akif Ersoy Üniversitesi Ĕ̆gitim Fakültesi Dergisi, (44), 598-620.

Uçar, M.E. ve Konal, B. (2017). Narsisizm kişilik özellikleri ve benlik saygısı arasındaki ilişkiler. Journal of Social and Humanities Sciences Researches, 4 (10), 260-280

Uçar, M.E.ve Aliyev, R. (2017). Lise öğrencilerinde etkileşim algısı eylem kimlikleme ve duygu ihtiyacı arasındaki ilişkiler. Journal of Kirsehir Education Faculty, 18(2), 55-73.

Vermulst, A. A., ve Gerris, J. R. M. (2005). QBF: Quick big five persoonlijkheidstest handleiding quick big five personality test manual. Leeuwarden, the Netherlands: LDC Publications.

Vernon, P. A., Villani, V. C., Vickers, L. C., ve Harris, J. A. (2008). A behavioral genetic investigation of the Dark Triad and the Big 5 . Personality and Individual Differences, 44(2), 445-452.

Wallace, H. M., ve Baumeister, R. F. (2002). The performance of narcissists rises and falls with perceived opportunity for glory. Journal of Personality and Social Psychology, 82(5), 819-834.

Weitten,W.,Hammer,Y.E.,Dunn,D.S. (2015). Psikoloji ve çă̆daş yaşam insan иуити. (Çev.Ed. Ebru İlkiz,2015). Ankara: Nobel yay.

Zajonc, R. B. (1980). Feeling and thinking: Preferences need no inferences. American psychologist, 35(2), 151-175.

\section{Kaynakça Bilgisi / Citation Information}

Uçar, M. E. ve Konal, B. (2018). Öğretmenler ile lise ve üniversite öğrencilerindeki narsisizm kişilik özellikleri benlik saygısı ve duygu gereksinimi arasındaki ilişkiler. OPUS - Uluslararası Toplum Araştırmaları Dergisi, 8(14), 92-136. DOI: 10.26466/opus.406591 